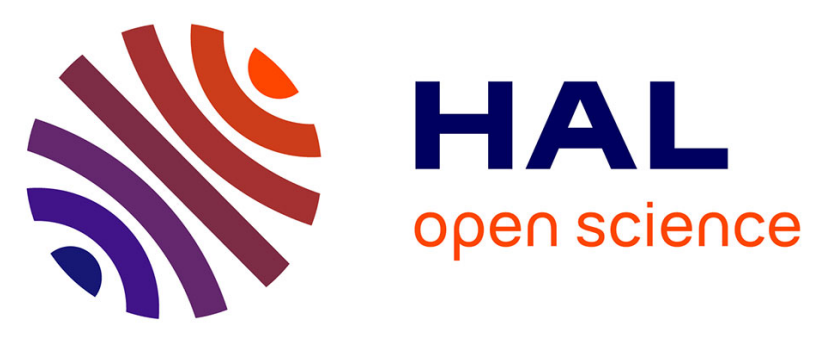

\title{
Soft-sediment crustacean diversity and distribution along the Portuguese continental shelf
}

Leandro Sampaio, Renato Mamede, Fernando Ricardo, Luisa Magalhaes, Helder Rocha, Roberto Martins, Jean-Claude Dauvin, Ana Maria Rodrigues, Victor Quintino

\section{To cite this version:}

Leandro Sampaio, Renato Mamede, Fernando Ricardo, Luisa Magalhaes, Helder Rocha, et al.. Softsediment crustacean diversity and distribution along the Portuguese continental shelf. Journal of Marine Systems, 2016, 163, pp.43 - 60. 10.1016/j.jmarsys.2016.06.011 . hal-01537650

\section{HAL Id: hal-01537650 https://hal.science/hal-01537650}

Submitted on 12 Jun 2017

HAL is a multi-disciplinary open access archive for the deposit and dissemination of scientific research documents, whether they are published or not. The documents may come from teaching and research institutions in France or abroad, or from public or private research centers.
L'archive ouverte pluridisciplinaire HAL, est destinée au dépôt et à la diffusion de documents scientifiques de niveau recherche, publiés ou non, émanant des établissements d'enseignement et de recherche français ou étrangers, des laboratoires publics ou privés. 


\title{
Soft-sediment crustacean diversity and distribution along the Portuguese continental shelf
}

\author{
Leandro Sampaio ${ }^{a}$, Renato Mamede ${ }^{a}$, Fernando Ricardo ${ }^{a}$, Luísa Magalhães a , Hélder Rocha ${ }^{a}$, Roberto Martins ${ }^{a}$, \\ Jean-Claude Dauvin ${ }^{\mathrm{b}}$, Ana Maria Rodrigues ${ }^{\mathrm{a}}$, Victor Quintino ${ }^{\mathrm{a}, *}$ \\ a CESAM and Department of Biology, University of Aveiro, 3810-193 Aveiro, Portugal \\ b UNICAEN, Université de Caen Normandie, Laboratoire Morphodynamique Continentale et Côtière, UMR CNRS 6143 M2C, 24 rue des Tilleuls, F-14000 Caen, France
}

\section{A R T I C L E I N F O}

\section{Article history:}

Received 3 February 2016

Received in revised form 5 May 2016

Accepted 22 June 2016

Available online 24 June 2016

\section{Keywords:}

Crustaceans

Portugal shelf

Western Mediterranean

Northeast Atlantic

North African

Macaronesian

\begin{abstract}
A B S T R A C T
This study analyzed the crustacean diversity, distribution and relationship with environmental factors in the western and the southern Portuguese continental shelf, between 10 and $200 \mathrm{~m}$ depth. A total of 10,639 specimens belonging to 242 taxa from 90 families were identified, mostly amphipods ( $55.8 \%$ of the total taxa). The mysid Gastrosaccus spinifer and the amphipods Socarnes erythrophthalmus and Cheirocratus sundevallii were the most abundant and the amphipods Ampelisca brevicornis, Leucothoe incisa and Autonoe spiniventris were the most frequent species. The highest abundance and diversity was found in coarser sediments with up to 306 individuals per $0.1 \mathrm{~m}^{2}$. Alpha diversity ranged from 1 to $28 \mathrm{sp} . / 0.1 \mathrm{~m}^{2}$. Moreover, this study confirmed six previously doubtful first records and added an additional 19 new records to the Portuguese fauna. The results also confirmed the Portuguese coast as a transition zone of mixed Atlantic and Mediterranean faunas and exposed a noticeable North African and Macaronesian influence. A multivariate analysis based on the abundance of crustaceans revealed six affinity groups characterized by: (a) C. sundevallii, Guernea (Guernea) coalita and Sarsinebalia cristoboi on very coarse sands; (b) G. spinifer, Nototropis falcatus and Pontocrates arenarius on coarse sands; (c) Othomaera othonis, Processa modica modica and Animoceradocus semiserratus on heterogeneous medium sands; (d) A. brevicornis, Urothoe pulchella and Necalianassa truncata on fine sands; (e) Ampelisca pectenata, Bodotria scorpioides and Astacilla dilatata on heterogeneous fine sands and (f) Callianassa subterranea, Ampelisca tenuicornis and Ampelisca typica on muddy fine sands. Sediment grain-size and depth were the variables best related to the benthic crustacean spatial distribution patterns along the Portuguese continental shelf.
\end{abstract}

(C) 2016 Elsevier B.V. All rights reserved.

\section{Introduction}

Crustacea represent a large group of segmented body animals with exoskeleton and characteristic double pair of antennae, mostly marine although also including a few freshwater and terrestrial species. The vast majority belong to the class Malacostraca which comprises $75 \%$ of all known crustaceans. Over 50,000 marine crustacean species have been described and accepted by marine taxonomists up to date, although many more are expected to be discovered (Appeltans et al., 2012), which makes it the largest and most diverse group of animals within the marine benthic communities (Ruppert and Barnes, 1994). Coastal shelf benthic communities' diversity and distribution have been studied in the past decades and multiple environmental factors were shown to affect them, namely sediment type, latitudinal gradients, organic matter content, nutrients, $\mathrm{pH}$, temperature, depth (Dauvin, 2015; Dolbeth et al., 2007; Hily et al., 2008; Levin and Gage, 1998).

\footnotetext{
* Corresponding author.

E-mail address: victor.quintino@ua.pt (V. Quintino).
}

The importance of these studies for the marine environment conservation and global biodiversity preservation is paramount as they continuously provide an historical record to monitor environmental impact and species diversity (Muñoz et al., 2008). Benthic communities change as they adapt to the prevailing situations and diverse communities show more plasticity thus additional resilience to environmental impacts (Hily et al., 2008).

Present day knowledge of the Portuguese coast macrobenthic communities is well established for estuaries (Moreira et al., 1993; Rodrigues and Quintino, 1993; Rodrigues et al., 2006, 2011, 2012), lagoons (Quintino et al., 1987, 1989) rocky shores (Araújo et al., 2005; Pereira et al., 2006; Saldanha, 1997) sandy beaches (Dexter, 1988; Vale et al., 2010), but less so for submarine canyons (Cunha et al., 2011; Cúrdia et al., 2004) or the continental shelf (Freitas et al., 2011; Marques and Bellan-Santini, 1991, 1993) where the most comprehensive studies are very recent (Martins et al., 2013a, 2013b, 2014). The Portuguese continental shelf, located in the Western Iberian coast, is a region of contact between cold waters from the North Atlantic and warm waters from northern Africa and the Mediterranean Sea. The 
western Portuguese shelf is dominated by an energetic regime of waves and tides and a complex current system, while the southern shelf is affected by warmer waters and characterized by a lower energy hydrodynamic regime, where the Atlantic inflow to the Mediterranean imposes eastward-directed current patterns (Fiúza, 1983). In terms of hydrodynamic regime, the Portuguese coast has been divided in three broad areas: mesotidal exposed Atlantic coast, from the northern Portuguese border to Cape Carvoeiro west coast, mesotidal moderately exposed Atlantic coast, from Cape Carvoeiro to Ponta da Piedade south coast and mesotidal sheltered Atlantic coast, from Ponta da Piedade to Vila Real de Santo António, the remaining southern coast (Bettencourt et al., 2004). This different regime along the coast affects the sedimentary cover of the Portuguese shelf, where coarser sediments characterize the northwestern shelf, muddy sands dominate the remaining western shelf and muds are mostly present in the sheltered southern shelf (Martins et al., 2012). The Portuguese shelf is also fractured by submarine canyons (depth range: 50-5000 m), of which the most outstanding are Nazaré, Cascais/Lisboa, Setúbal, and S. Vicente, which cause morphological, sedimentary and hydrological boundaries (Oliveira et al., 2007).
The aim of this study was to characterize the diversity and distribution of the crustacean fauna along the western and southern Portuguese continental shelf and discuss the relationships between the biological and environmental data.

\section{Study site}

This study comprises data collected in sampling campaigns conducted on the entire Portuguese continental shelf. The study area extends from Caminha on the Northwest $\left(41^{\circ} 51.8^{\prime} \mathrm{N}, 9^{\circ} 15.6^{\prime} \mathrm{W}\right)$ to Vila Real de Santo António on the Southeast $\left(36^{\circ} 56.1^{\prime} \mathrm{N}, 7^{\circ} 24.7^{\prime} \mathrm{W}\right)$. The survey was more detailed from Porto to the North of Nazaré Canyon, where the coastal shelf is the widest (Fig. 1) and soft sediments dominate the seascape. The detailed results from grain-size analysis and the spatial distribution of superficial sediments are given in Mamede et al. (2015) and Martins et al. (2012). The shallow and mid depth northwestern shelf and areas located close to the major submarine canyons are characterized by coarser sediments with low fines and organic matter content, whereas the southwestern and the deep northwestern shelf are

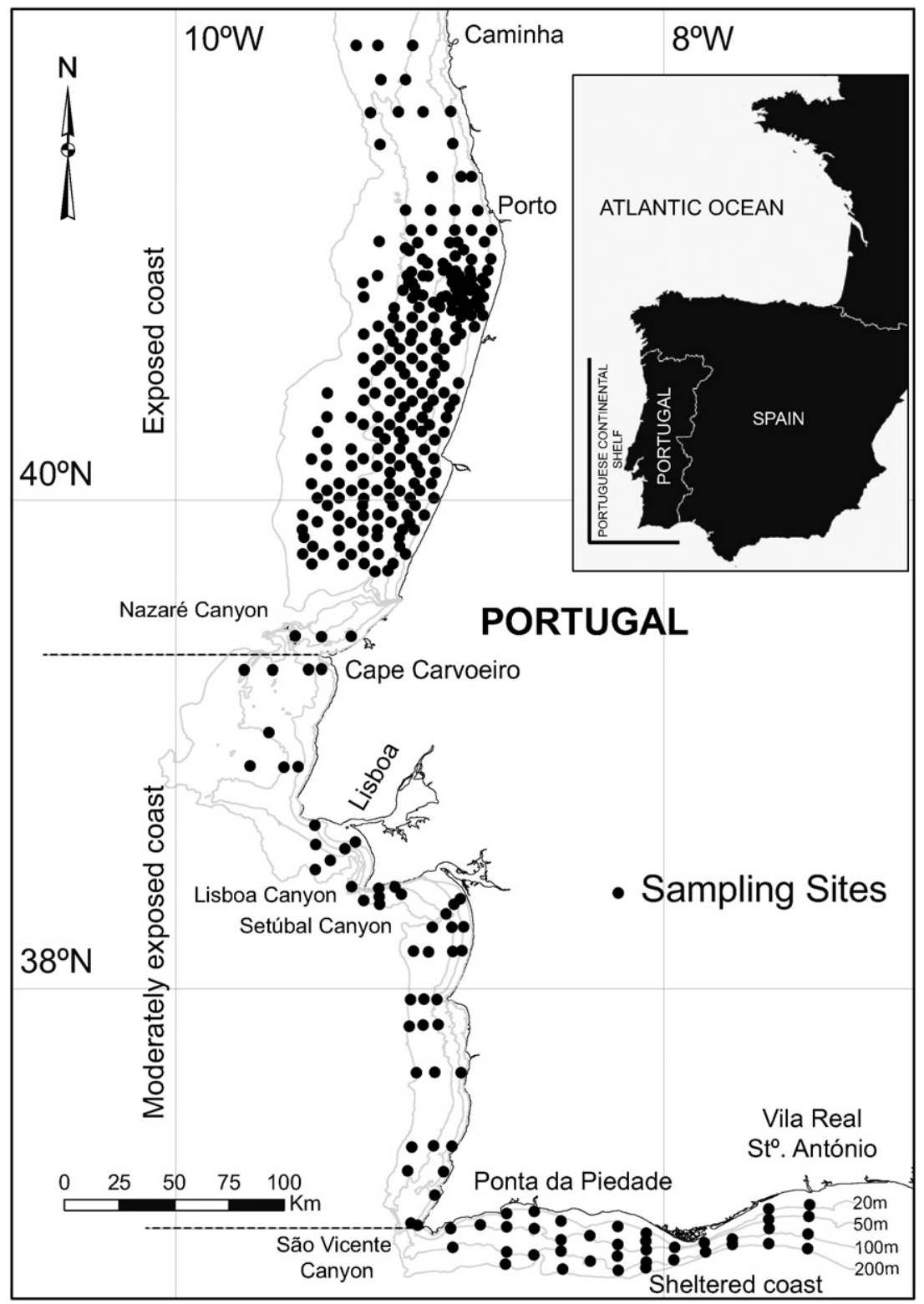

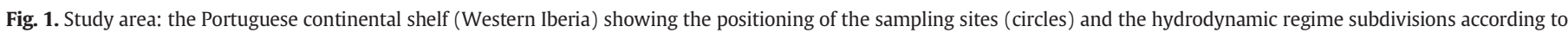
Bettencourt et al. (2004). 
dominated by fine sands with moderate fines and organic matter content. The western part of the southern shelf is very heterogeneous while muds predominate off the major Portuguese rivers, the Tagus (Lisbon) and the Douro (Porto) on the west and the Guadiana (Vila Real Santo de António), on the south coast (Mamede et al., 2015; Martins et al., 2012).

\section{Sampling}

A total of 326 sites were visited, distributed in perpendicular lines to the coastline, and with depth ranging from 10 to $200 \mathrm{~m}$ (cf. Fig. 1). At each site, two sediment samples were collected with a $0.1 \mathrm{~m}^{2}$ SmithMcIntyre grab, one to study the macrofauna and the other for grainsize analysis. Macrofauna samples were sieved on board over $1 \mathrm{~mm}$ mesh size and the residue fixed in neutralized formalin (4\%) and stained with rose Bengal. In the laboratory, macrofauna samples were rinsed with water, hand sorted and the fauna preserved in ethyl alcohol (70\%). Crustaceans were identified to the lowest possible taxonomic level, whenever possible, following the faunas of Allen (1967); Bellan-Santini et al. (1982, 1989, 1993); Bouvier (1940); Gurriarán and Méndez (1985); Holdich and Jones (1983); Ingle (1983); Ingle (1993); Ingle and Christiansen (2004); Jones (1976); Lincoln (1979); Mauchline (1984); Moreira et al. (2009); Naylor (1972); NilssonCantell (1978); Smaldon (1979); Tattersall and Tattersall (1951); Zariquiey Alvarez (1968), and specialized papers on crustacean systematic and specimens were counted under a binocular stereomicroscope. Scientific names are in accordance with the World Register of Marine Species (WoRMS - http://www.marinespecies.org).

\section{Data analysis}

Abundance, species richness and diversity measurements were calculated per sampling site and mean values were obtained per sediment type, depth classes ( $<30 \mathrm{~m}, 30-60 \mathrm{~m}, 60-100 \mathrm{~m}$ and $>100 \mathrm{~m}$ ), hydrodynamic regime areas (exposed $=1$; moderately exposed $=2$; sheltered $=3$ ), latitudinal degree on the western shelf and longitudinal degree on the southern shelf, and major shelf areas (western, southern and the entire shelf). Alpha diversity corresponds to the total quantity of species per sampling unit $\left(0.1 \mathrm{~m}^{2}\right)$. Beta or turnover diversity corresponds to the extent of biotic change or species replacement along an environmental gradient (Gray, 2000; Whittaker, 1960) and was calculated for all the above categories, except per sampling site. It was obtained by dividing the mean alpha diversity per sample in a given category, by the total number of species found in that same category (Whittaker, 1960). As an example, beta diversity for the whole Portuguese shelf corresponded to the ratio between the mean alpha diversity of the whole set of samples and the total number of species recorded in this study. Other diversity indices were also calculated per site, to complement and comprehend the spatial variation of the diversity along the Portuguese shelf, namely, Shannon-Wiener diversity $\left(\mathrm{H}^{\prime} ; \log _{2}\right)$, Margalef richness (d), Pielou evenness $\left(\mathrm{J}^{\prime}\right)$, and Simpson diversity $\left(1-\lambda^{\prime}\right)$ (Clarke and Gorley, 2006).

The data matrix with the macrofauna abundance per site was fourth root transformed to lower the influence of the most abundant species on the Bray-Curtis similarity calculated between sites. The similarity matrix was analyzed in PRIMER v.6 (Clarke and Gorley, 2006) using agglomerative hierarchical clustering, with the un-weighted pair-group mean average algorithm (UPGMA), to define the similarity between a pair of samples through a simple average, and ordination analysis, with non-metric multidimensional scaling (NMDS). These techniques were used for the identification of the biological affinity groups, also named assemblages throughout the text. The biological groups were characterized according to their mean abundance, species richness, alpha and beta diversity, Shannon-Wiener diversity $\left(\log _{2}\right)$, Pielou evenness, Margalef richness, Simpson index, sediment baseline data, number of exclusive species and characteristic species. The characteristic species of each assemblage were obtained following their constancy (C) and fidelity (F) in the assemblage. The constancy corresponds to a sampling frequency and is given by the number of sites where the species was sampled expressed as a percentage of the total number of sites in the assemblage (Dajoz, 1971). The fidelity corresponds to the ratio between the species constancy in a given assemblage and the sum of the constancies of the same species in all the assemblages where it exists (Retière, 1979). For constancy, species were classified into constant (C $>50.0 \%)$, common $(50.0 \geq \mathrm{C}>25.0 \%)$, occasional $(25.0 \geq \mathrm{C}>12.5 \%)$ and rare ( $\mathrm{C} \leq 12.5 \%)$, and for fidelity into elective ( $\mathrm{F}>90.0 \%)$, preferential (90 $\geq F>66.6 \%)$, indifferent (66.6 $\geq F>33.3 \%)$, accessory (33.3 $\geq \mathrm{F}>10.0 \%$ ) and accidental ( $\mathrm{F} \leq 10.0 \%)$. The characteristic species per affinity group were selected following the highest product between the constancy and fidelity indices.

The relationship between the biological and the environmental data was analyzed with the BIOENV procedure using the Spearman correlation coefficient (Clarke and Gorley, 2006) and considering the environmental variables depth, median grain-size, gravel, sand, fines, hydrodynamic regime and latitude. The environmental data was obtained from Mamede et al. (2015) and Martins et al. (2012). The abundance, alpha diversity, Shannon-Wiener diversity and Pielou evenness per site, and the representation of the affinity groups were plotted with ArcGis 10 in a GIS environment.

\section{Results}

\subsection{Abundance and diversity gradients}

A total of 10,639 specimens of crustacea were identified corresponding to 90 families and 242 taxa: 135 Amphipoda, 45 Decapoda, 25 Isopoda, 15 Cumacea, 11 Mysida and 11 miscellanea taxa (Euphausiacea, Lophogastrida, Cirripedia, Leptostraca, Ostracoda and Tanaidacea). The most abundant families were Mysidae, Ampeliscidae, Lysianassidae, Maeridae and Cheirocratidae (1407, 1235, 697, 584, 492 total specimens, respectively) and those with the highest number of species were Ampeliscidae, Mysidae, Lyssianassidae, Oedicerotidae, Bathyporeiidae and Bodotridae (19, 11, 10, 9, 8, 8 species respectively).

The most abundant species were the mysid Gastrosaccus spinifer (8.7\% of total abundance, $A_{T}$ ), then the amphipods Socarnes erythrophthalmus $\left(A_{T}=5.0 \%\right)$, C. sundevalli $\left(A_{T}=4.6 \%\right)$, Ampelisca brevicornis $\left(A_{T}=4.0 \%\right)$ and 0 . othonis $\left(A_{T}=4.0 \%\right)$. The most frequent species $(F$, expressed in percentage and given by the ratio between the number of sites where the species was sampled and the total number of sites) were the amphipods A. brevicornis $(\mathrm{F}=26.1 \%)$, Leucothoe incisa $(\mathrm{F}=22.7 \%)$, A. spiniventris $(\mathrm{F}=20.3 \%)$, C. sundevalli $(\mathrm{F}=$ $18.2 \%)$, Guernea coalita $(\mathrm{F}=16.1 \%)$ and 0 . othonis $(\mathrm{F}=16.1 \%)$. The number of rare species was high: $25.6 \%$ of the species were represented by only $1-2$ specimens and $34.3 \%$ were confined to $1-2$ sites.

Abundance ranged from 0 (in four mud sites) to 306 (one site in medium sand) specimens per site $\left(0.1 \mathrm{~m}^{2}\right.$, Fig. $\left.2 \mathrm{~A}\right)$. The highest mean abundances (Table 1 ) were obtained in gravel ( 89.4 ind. $\left./ 0.1 \mathrm{~m}^{2}\right)$, at mid depth (30-60 m water depth; 56.0 ind./ $/ 0.1 \mathrm{~m}^{2}$ ) and in the northern latitudes (latitude $40-41^{\circ} \mathrm{N}, 41.7$ ind./ $0.1 \mathrm{~m}^{2}$ ). The lowest mean abundances (Table 1 ) were found in the central region (latitude $38^{\circ}-39^{\circ}$, 7.8 ind. $\left./ 0.1 \mathrm{~m}^{2}\right)$, in the deep shelf $\left(>100 \mathrm{~m} ; 8.9\right.$ ind. $\left./ 0.1 \mathrm{~m}^{2}\right)$ and in mud sediments ( 9.5 ind./ $0.1 \mathrm{~m}^{2}$ ). Overall, the crustacean abundance decreased from coarser to finer sediments, from shallow to deeper areas, from the north to the south in the western shelf and from west to east in the southern shelf.

Alpha diversity (Fig. 2B) ranged from 1 to $28 \mathrm{spp} . / 0.1 \mathrm{~m}^{2}$ (Fig. 2B). The highest mean alpha diversity (Table 1 ) was found in gravel (14.7 spp./ $0.1 \mathrm{~m}^{2}$ ), in the southwestern sheltered shelf (longitude $8^{\circ}-8.99^{\circ} \mathrm{W}$; $12.4 \mathrm{spp} . / 0.1 \mathrm{~m}^{2}$ ) and at mid depth (30-60 m water depth; $11.7 \mathrm{spp} . /$ $0.1 \mathrm{~m}^{2}$ ). The lower values of mean alpha diversity (Table 1 ) were obtained in mud ( $4.5 \mathrm{spp} . / 0.1 \mathrm{~m}^{2}$ ), in the deep shelf (>100 m; $5.1 \mathrm{spp} . / 0.1 \mathrm{~m}^{2}$ ) and in the central region (latitude $38^{\circ}-39^{\circ}, 5.3 \mathrm{spp} . / 0.1 \mathrm{~m}^{2}$ ) (Table 1 ). 

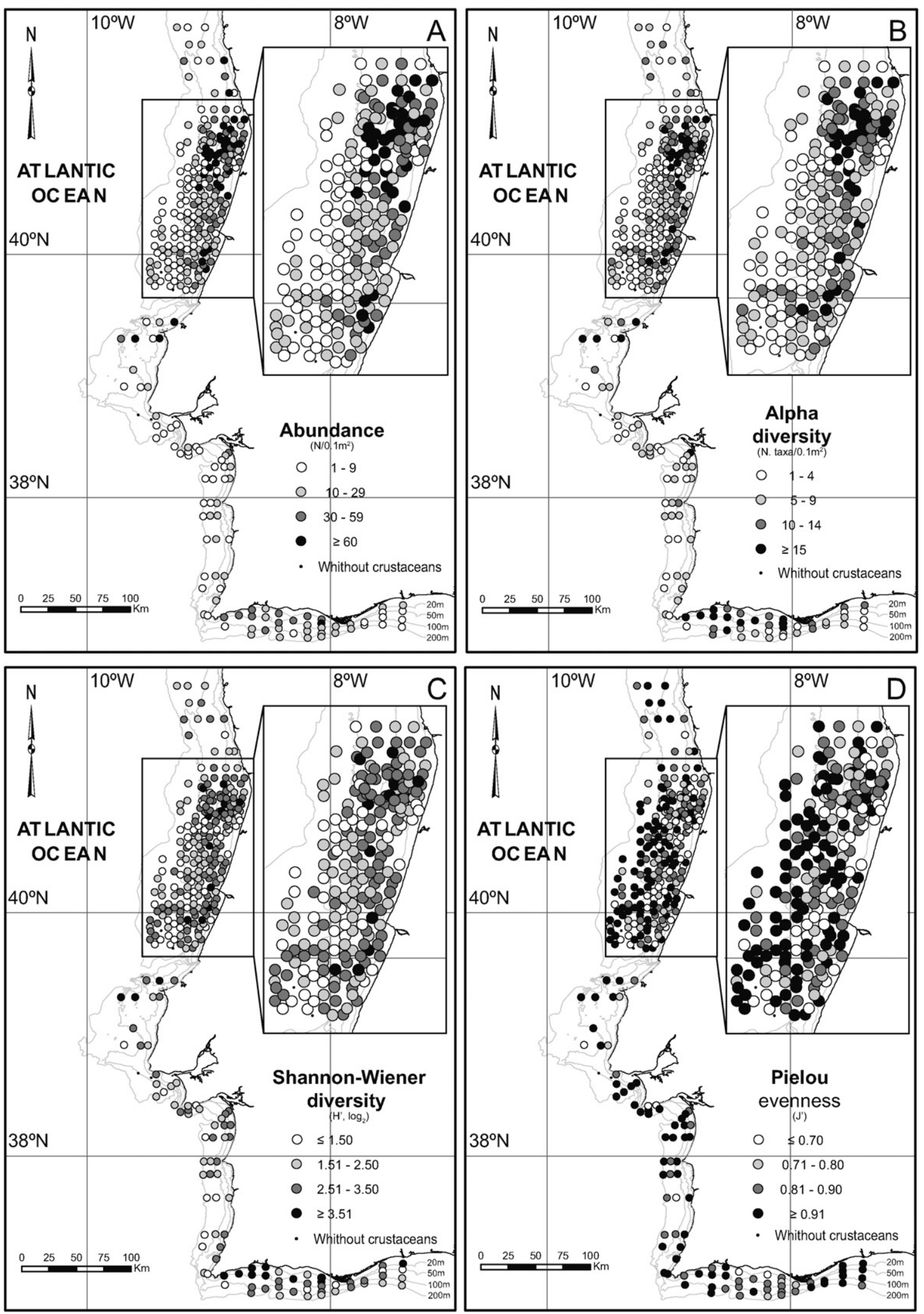

Fig. 2. Spatial distribution of crustacean abundance (A), Alpha diversity (B), Shannon-Wiener diversity (C) and Pielou evenness (D) in the Portuguese continental shelf.

The lowest mean beta diversity (spatial turnover; cf. Table 1 ) was found in gravel $(\beta=7.2)$, in the southern latitudes (latitude $37^{\circ}-$ $38^{\circ} \mathrm{N} ; \beta=9.3$ ) and in the southwestern sheltered shelf (longitude $\left.8^{\circ}-8.99^{\circ} \mathrm{W} ; \beta=9.3\right)$, while the highest mean beta diversity
(Table 1 ) was found in the deep shelf $(\beta=23.6)$, in the exposed shelf $(\beta=23.1)$ and in the latitude $40-41^{\circ} \mathrm{N}(\beta=20.3)$.

The highest values of the diversity indices [Shannon-Wiener $\left(\mathrm{H}^{\prime}>3.5\right.$, Fig. 2C) and Margalef richness $\left.(\mathrm{d}>4.0)\right]$ were obtained in 
Table 1

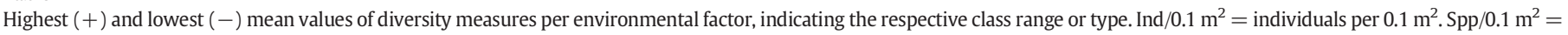
species per $0.1 \mathrm{~m}^{2}$.

\begin{tabular}{|c|c|c|c|c|c|c|}
\hline & & Hydrodynamic regime & Sediment type & Depth & Latitude & Longitude \\
\hline \multirow[t]{2}{*}{ Abundance (ind $/ 0.1 \mathrm{~m}^{2}$ ) } & + & Exposed 37.8 & Gravel 89.4 & $30-59$ m 56.4 & $40-41^{\circ} \mathrm{N} 41.7$ & $8^{\circ}-8.99^{\circ} \mathrm{W} 28.9$ \\
\hline & - & Moderately exposed 13.6 & Silt 9.5 & $100-195$ m 8.9 & $38-39^{\circ} \mathrm{N} 7.8$ & $7^{\circ}-7.99^{\circ} \mathrm{W} 11.6$ \\
\hline \multirow[t]{2}{*}{ Alpha diversity (spp/0.1 m²) } & + & Sheltered 10.2 & Gravel 14.7 & 30-59 m 11.7 & $41-42^{\circ} \mathrm{N} 9.2$ & $8^{\circ}-8.99^{\circ} \mathrm{W} 12.4$ \\
\hline & - & Moderately exposed 6.5 & Silt 4.5 & $100-195$ m 5.1 & $38-39^{\circ} \mathrm{N} 5.3$ & $7^{\circ}-7.99^{\circ} \mathrm{W} 6.7$ \\
\hline \multirow[t]{2}{*}{ Beta diversity } & + & Exposed 23.1 & Fine sand 19.8 & $100-195$ m 23.6 & $40-41^{\circ} \mathrm{N} 20.3$ & $7^{\circ}-7.99^{\circ} \mathrm{W} 8.3$ \\
\hline & - & Sheltered 11.4 & Gravel 7.2 & $0-29 \mathrm{~m} 11.0$ & $37-38^{\circ} \mathrm{N} 9.3$ & $8^{\circ}-8.99^{\circ} \mathrm{W} 8.2$ \\
\hline \multirow[t]{2}{*}{ Margalef (d) } & + & Sheltered 3.0 & Gravel 3.3 & $30-59$ m 2.9 & $39-40^{\circ} \mathrm{N} 2.7$ & $8^{\circ}-8.99^{\circ} \mathrm{W} 3.4$ \\
\hline & - & Moderately exposed 2.4 & Silt 2.0 & $100-195$ m 2.1 & $37-38^{\circ} \mathrm{N} 2.0$ & $7^{\circ}-7.99^{\circ} \mathrm{W} 2.4$ \\
\hline \multirow[t]{2}{*}{ Pielou's evenness $\left(\mathrm{J}^{\prime}\right)$} & + & Moderately exposed 0.93 & Silt 0.90 & $100-195$ m 0.92 & $38-39^{\circ} \mathrm{N} 0.94$ & $7^{\circ}-7.99^{\circ} \mathrm{W} 0.92$ \\
\hline & - & Exposed 0.83 & Coarse sand 0.81 & $0-29$ m 0.79 & $40-41^{\circ} \mathrm{N} 0.83$ & $8^{\circ}-8.99^{\circ} \mathrm{W} 0.86$ \\
\hline \multirow[t]{2}{*}{ Shannon-Wiener $\left(\mathrm{H}^{\prime}, \log 2\right)$} & + & Sheltered 2.7 & Gravel 3.0 & $30-59 \mathrm{~m} 2.7$ & $41-42^{\circ} \mathrm{N} 2.5$ & $8^{\circ}-8.99^{\circ} \mathrm{W} 2.9^{2}$ \\
\hline & - & Exposed 2.3 & Silt 1.7 & $100-195$ m 2.0 & $37-38^{\circ} \mathrm{N} 2.1$ & $7^{\circ}-7.99^{\circ} \mathrm{W} 2.3$ \\
\hline \multirow[t]{2}{*}{ Simpson $\left(1-\lambda^{\prime}\right)$} & + & Moderately exposed 0.87 & Gravel 0.84 & $100-195 \mathrm{~m} 0.84$ & $38-39^{\circ} \mathrm{N} 0.87$ & $7^{\circ}-7.99^{\circ} \mathrm{W} 0.86$ \\
\hline & - & Exposed 0.80 & Coarse sand 0.75 & $0-29 \mathrm{~m} 0.75$ & $40-41^{\circ} \mathrm{N} 0.79$ & $8^{\circ}-8.99^{\circ} \mathrm{W} 0.85$ \\
\hline
\end{tabular}

shallow depth areas (in the southwestern shelf, off Sesimbra, off Peniche and in the northernmost sector) with coarse sediments and in the western part of the southern shelf. Low diversity values were found far from the coast in muds and sands and deeper areas. High values of Pielou's evenness ( $\mathrm{J}^{\prime}>0.95$, Fig. 2D) and Simpson $(>0.95)$ were recorded in muds and fine sands at deep depths (off Sesimbra and Peniche and in the southern shelf).

\subsection{Multivariate analysis}

The multivariate analysis of the abundance data is shown in Fig. 3 and the spatial representation of the affinity groups in Fig. 4. Six crustacean assemblages were identified: A, B1, B2, C1, C2, and C3, obtained at a level of similarity of $6.5 \%$. Ten sites appeared isolated due to their particular species composition and low abundance and were removed from the final analysis. The NMDS horizontal dimension was high correlated
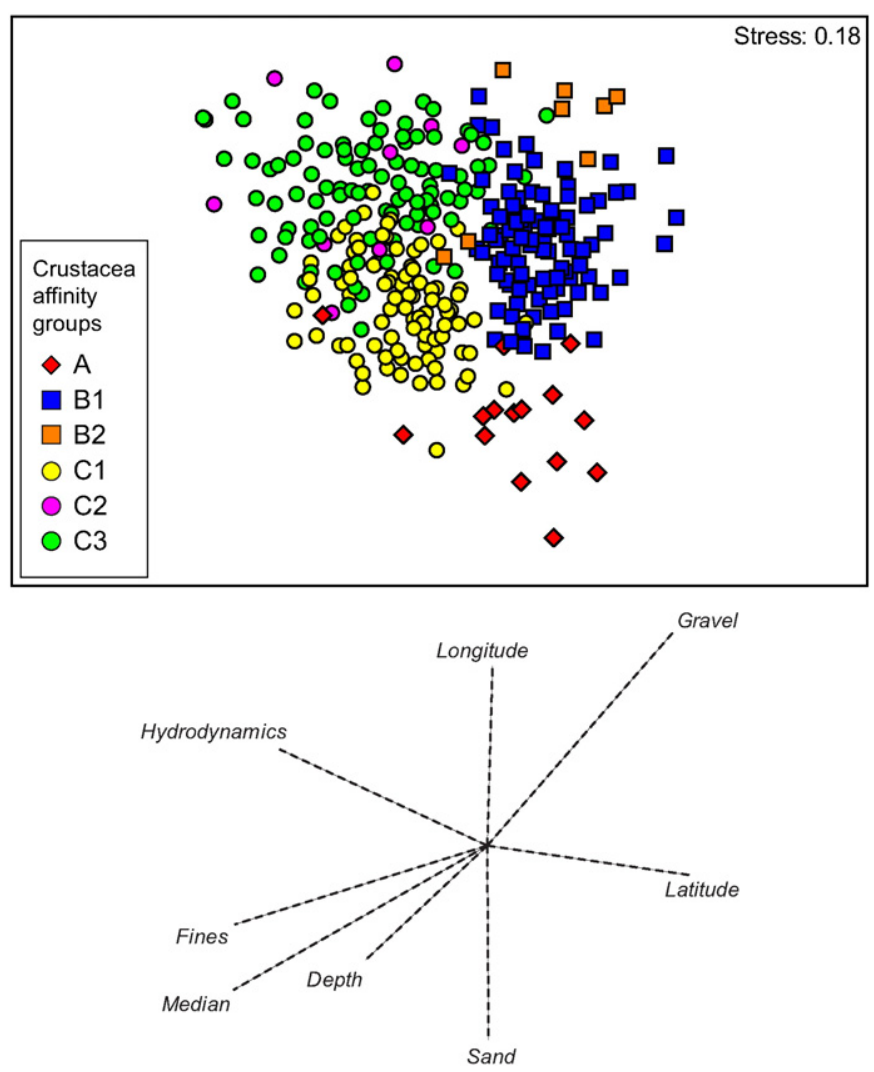

Fig. 3. Ordination diagram (NMDS) based on the abundance of crustaceans. with the sediment fines content and median and the hydrodynamic regime areas (Spearman rho $=-0.85,-0.85$ and -0.70 , respectively, Fig. 3). It separated coarser from finer sediment sites (groups A and B vs group $\mathrm{C}$ ). The NMDS vertical dimension separated groups $\mathrm{A}$ and $\mathrm{C} 1$ from groups B1 and B2 with C2. This axis discriminated the nearshore coarse sediments from the deeper sandier sites and presented high correlation with gravel, sand content and longitude $(0.72,-0.65$ and 0.60 , respectively).

The biological and environmental characterization of the six crustacean assemblages is summarized in Tables 2 and 3. Group A presented the lowest alpha diversity ( $4.4 \mathrm{spp} . / 0.1 \mathrm{~m}^{2}$ ) and the highest mean abundance ( 61 ind $/ 0.1 \mathrm{~m}^{2}$ ). The most abundant and characteristic species was $G$. spinifer (mean $\mathrm{N}=46.0$ ind $/ 0.1 \mathrm{~m}^{2}, \mathrm{C}=80.0 \%, \mathrm{~F}=85.9 \%$, Tables 2 and 3). Haustorius arenarius was the only exclusive species found in this group, comprising 15 sites located mainly in nearshore coarser sediments of the mid-western shelf (Fig. 4).

Group B1 included 93 sites located mainly in moderate depth distributed throughout the continental shelf and characterized by the highest gravel content (34.0\%) and very low fines (2.0\%). It exhibited very high abundance $\left(60\right.$ ind $/ 0.1 \mathrm{~m}^{2}$ ) and the highest alpha diversity (12.0 spp./0.1 $\mathrm{m}^{2}$ ) and exclusive species count (29 spp., cf. Table 2). S. erythrophthalmus (mean $\mathrm{N}=5.4 \mathrm{ind} / 0.1 \mathrm{~m}^{2}$, cf. Table 3) and $C$. sundevalli ( $\mathrm{C}=58.1 \%, \mathrm{~F}=72.5 \%$ ) were the most abundant and characteristic species, respectively.

Group B2 showed low mean abundance (11 ind/0.1 $\mathrm{m}^{2}$ ) and alpha diversity (5.9 spp. $/ 0.1 \mathrm{~m}^{2}$ ). The most characteristic species was $O$. othonis ( $\mathrm{C}=88.9 \%, \mathrm{~F}=57.5 \%$ ) and the most abundant was A. serratus (mean $\mathrm{N}=1.3$ ind $/ 0.1 \mathrm{~m}^{2}$, cf. Table 3 ). The number of exclusive species was also low ( 3 spp., cf. Table 2). This group comprised 9 sites located mainly in the mid shelf area, characterized by heterogeneous sediment composition.

Group C1 included 88 sites located mainly in fine sand (75\% of the sites), in the mid-western shelf area. It presented relatively high species richness (151 spp.) and moderate mean abundance $\left(29\right.$ ind $/ 0.1 \mathrm{~m}^{2}$ ), with 25 exclusive species (cf. Table 2). A. brevicornis (mean $\mathrm{N}=$ 4.4 ind $/ 0.1 \mathrm{~m}^{2}, \mathrm{C}=77.3 \%, \mathrm{~F}=58.4 \%$, Tables 2 and 3 ) was the most characteristic and abundant species.

Group C2 presented very low mean abundance ( $11 \mathrm{ind} / 0.1 \mathrm{~m}^{2}$ ) and species richness (40 spp.) and 2 exclusive species (Tables 2 and 3 ). Ampelisca pectenata (mean $\mathrm{N}=1.2$ ind $/ 0.1 \mathrm{~m}^{2}, \mathrm{C}=70.0 \%, \mathrm{~F}=82.9 \%$, Tables 2 and 3 ) was the most characteristic and abundant. The group comprised 10 sites located deeper and mainly in the southwestern shelf, characterized by moderate percentage of fines (19.7\%) and very low gravel content (3.1\%).

Group C3 gathered 101 sites distributed throughout the continental shelf, mostly over fine and very fine sand and mud, characterized by the highest percentage of fines (34.7\%) and a high mean depth (103.0 m). It exhibited high species richness (147 spp., mostly in finer sands) with 


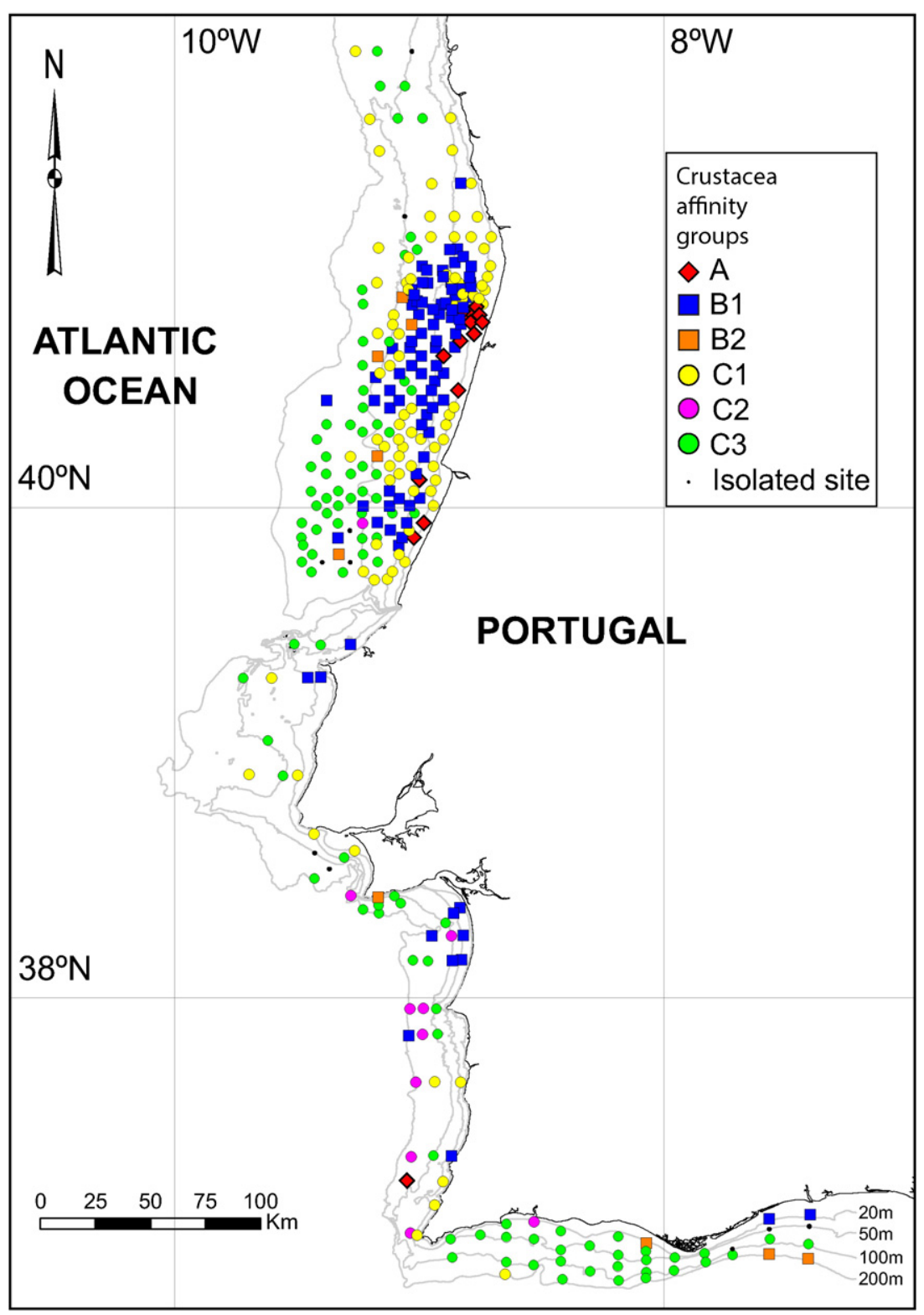

Fig. 4. Spatial distribution of the crustacean communities in the Portuguese continental shelf.

low mean abundance $\left(14 \mathrm{ind} / 0.1 \mathrm{~m}^{2}\right)$. Callianassa subterranea $(\mathrm{C}=$ $33.7 \%, \mathrm{~F}=78.7 \%$ ) and Ampelisca tenuicornis (mean $\mathrm{N}=1.6 \mathrm{ind} /$ $0.1 \mathrm{~m}^{2}$, cf. Table 3) were the most characteristic and abundant. The number of exclusive species was close to $20 \%$ of the total species richness (27 spp., cf. Table 2 ).

The environmental variables best related to the biological data were depth, sediment median, gravel and fines content (BIOENV, rho $=0.316$ ).

Fig. 5 shows the abundance distribution of selected species, chosen among the two most characteristic within each assemblage (cf. section 3.2) and with the highest abundance and/or frequency. With the exception of G. spinifer (up to 306 ind $/ 0.1 \mathrm{~m}^{2}$, Fig. 5D) and Apherusa bispinosa (up to 71 ind $/ 0.1 \mathrm{~m}^{2}$ ) inhabiting coarser sediments in the northwestern area (up to latitude $40^{\circ} \mathrm{N}$ ), the majority of the most frequent and abundant species occurred along most of the entire shelf (at least up to latitude $38^{\circ} \mathrm{N}$ ). Cheirocratus sundevalli (up to 43 ind $/ 0.1 \mathrm{~m}^{2}$, Fig. $5 \mathrm{C}$ ), Megamphopus cornutus (up to $15 \mathrm{ind} / 0.1 \mathrm{~m}^{2}$ ), 0 . othonis (up to $37 \mathrm{ind} /$ $0.1 \mathrm{~m}^{2}$, Fig. $5 \mathrm{~F}$ ) and S. erythrophthalmus (up to $261 \mathrm{ind} / 0.1 \mathrm{~m}^{2}$ ) were recorded in coarse sediments throughout the entire shelf. Galathea intermedia (up to 37 ind $/ 0.1 \mathrm{~m}^{2}$ ), G. coalita (up to 45 ind $/ 0.1 \mathrm{~m}^{2}$, Fig. 5H), Haplostylus normani (up to 194 ind $/ 0.1 \mathrm{~m}^{2}$ ), Psammogammarus caecus (up to $16 \mathrm{ind} / 0.1 \mathrm{~m}^{2}$ ) and $S$. cristoboi (up to $81 \mathrm{ind} / 0.1 \mathrm{~m}^{2}$ ) were more abundant in very coarse sand and gravel in the northwestern and central areas. Ampelisca brevicornis (up to 37 ind $/ 0.1 \mathrm{~m}^{2}$, Fig. 5A), A. tenuicornis (up to 28 ind $/ 0.1 \mathrm{~m}^{2}$, Fig. 5B), Diastylis bradyi (up to 35 ind $/ 0.1 \mathrm{~m}^{2}$ ), N. truncata (up to 26 ind $/ 0.1 \mathrm{~m}^{2}$ ), Pariambus typicus (up to 53 ind $/ 0.1 \mathrm{~m}^{2}$ ) and Urothoe pulchella (up to 20 ind $/ 0.1 \mathrm{~m}^{2}$, Fig. 5E) were more abundant in finer sediments along the entire shelf, with the exception of the southern sector where P. typicus was not record. Autonoe spiniventris (up to 6 ind $/ 0.1 \mathrm{~m}^{2}$ ), Bodotria scorpioides (up to $77 \mathrm{ind} / 0.1 \mathrm{~m}^{2}$, Fig. $5 \mathrm{G}$ ) and L. incisa (up to $12 \mathrm{ind} / 0.1 \mathrm{~m}^{2}$ ) showed preference for very fine, fine and very coarse sand, distributed troughout the shelf.

\section{Discussion and conclusion}

\subsection{Diversity and distribution patterns}

This study revealed a high diversity of crustaceans in the Portuguese soft bottom continental shelf (10 to $200 \mathrm{~m}$ depth), comprising 242 taxa and $>10.000$ specimens, corresponding approximately to $26 \%$ and $9 \%$ of 
Table 2

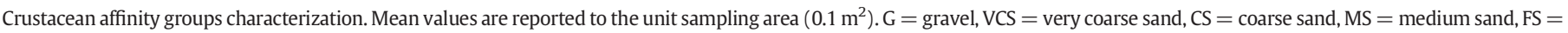

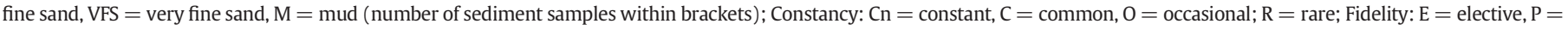
preferencial, I = Indifferent, A = accessory; ${ }^{*}=$ Exclusive species in each group.

\begin{tabular}{|c|c|c|c|c|c|c|}
\hline Affinity groups & A & B1 & B2 & $\mathrm{C} 1$ & $\mathrm{C} 2$ & $\mathrm{C} 3$ \\
\hline Nr. of sampling sites & 15 & 93 & 9 & 88 & 10 & 101 \\
\hline Main sediment type & Coarse sand & Very coarse sand & Medium sand & Fine sand & Fine sand & Fine sand \\
\hline Sites median agreement & $\begin{array}{l}\mathrm{CS}(8), \mathrm{MS}(5) \\
\mathrm{G}(1), \mathrm{FS}(1)\end{array}$ & $\begin{array}{l}\operatorname{VCS}(51), \mathrm{G}(21) \\
\mathrm{CS}(10), \mathrm{FS}(4), \operatorname{MS}(1)\end{array}$ & $\begin{array}{l}\operatorname{VCS}(3), \operatorname{MS}(3) \\
\operatorname{CS}(2), \mathrm{FS}(1)\end{array}$ & $\begin{array}{l}\mathrm{FS}(66), \operatorname{VFS}(7), \operatorname{VCS}(4), \\
\mathrm{G}(3), \mathrm{CS}(3), \mathrm{MS}(3), \mathrm{M}(2)\end{array}$ & $\begin{array}{l}\mathrm{FS}(4), \mathrm{CS}(2) \\
\operatorname{MS}(2), \mathrm{VFS}(2)\end{array}$ & $\begin{array}{l}\mathrm{FS}(34), \operatorname{VFS}(26), \mathrm{M}(25), \\
\operatorname{VCS}(6), \mathrm{CS}(3), \mathrm{G}(2)\end{array}$ \\
\hline Gravel content (mean, \%) & 11.3 & 34.0 & 11.2 & 3.7 & 3.1 & 3.9 \\
\hline Sand content (mean, \%) & 87.8 & 64.0 & 65.2 & 89.3 & 77.1 & 61.4 \\
\hline Fines content (mean, \%) & 1.0 & 2.0 & 23.6 & 7.1 & 19.7 & 34.7 \\
\hline Depth (mean, m) & 35.4 & 61.5 & 99.1 & 63.8 & 120.3 & 103.0 \\
\hline Abundance (mean) & 61 & 60 & 11 & 29 & 11 & 14 \\
\hline Total species richness & 30 & 151 & 36 & 132 & 40 & 147 \\
\hline Alpha diversity (mean) & 4.4 & 12.0 & 5.9 & 8.4 & 6.5 & 7.5 \\
\hline Beta diversity (within the group) & 6.8 & 12.6 & 6.1 & 15.7 & 6.2 & 19.7 \\
\hline Shannon-Wiener (mean; $\mathrm{H}^{\prime}, \log 2$ ) & 1.2 & 2.8 & 1.8 & 2.4 & 2.3 & 2.3 \\
\hline Pielou's evenness (mean; J') & 0.6 & 0.8 & 0.9 & 0.8 & 0.9 & 0.9 \\
\hline Margalef (mean; d) & 1.1 & 3.0 & 2.4 & 2.4 & 2.3 & 2.6 \\
\hline Simpson (mean; $\left.1-\lambda^{\prime}\right)$ & 0.5 & 0.8 & 0.8 & 0.8 & 0.9 & 0.9 \\
\hline Nr. of exclusive species & 1 & 29 & 3 & 25 & 2 & 27 \\
\hline \multirow[t]{15}{*}{$\begin{array}{l}\text { Characteristic species (with } \\
\text { Constancy and Fidelity } \\
\text { indications) }\end{array}$} & $\begin{array}{l}\text { Gastrosaccus } \\
\text { spinifer }(\mathrm{Cn} / \mathrm{P})\end{array}$ & $\begin{array}{l}\text { Cheirocratus } \\
\text { sundevalli }(\mathrm{Cn} / \mathrm{P})\end{array}$ & $\begin{array}{l}\text { Othomaera othonis } \\
(\mathrm{Cn} / \mathrm{I})\end{array}$ & Ampelisca brevicornis $(\mathrm{Cn} / \mathrm{I})$ & $\begin{array}{l}\text { Ampelisca } \\
\text { pectenata } \\
(\mathrm{Cn} / \mathrm{P})\end{array}$ & $\begin{array}{l}\text { Callianassa subterranea } \\
(\mathrm{C} / \mathrm{P})\end{array}$ \\
\hline & $\begin{array}{l}\text { Nototropis } \\
\text { falcatus }(\mathrm{Cn} / \mathrm{P})\end{array}$ & $\begin{array}{l}\text { Guernea (Guernea) } \\
\text { coalita }(\mathrm{Cn} / \mathrm{P})\end{array}$ & $\begin{array}{l}\text { Processa modica } \\
\text { modica }(\mathrm{C} / \mathrm{P})\end{array}$ & Urothoe pulchella (C/P) & $\begin{array}{l}\text { Bodotria } \\
\text { scorpioides } \\
(\mathrm{Cn} / \mathrm{P})\end{array}$ & $\begin{array}{l}\text { Ampelisca tenuicornis } \\
(\mathrm{C} / \mathrm{P})\end{array}$ \\
\hline & $\begin{array}{l}\text { Pontocrates } \\
\text { arenarius }(\mathrm{C} / \mathrm{I})\end{array}$ & $\begin{array}{l}\text { Sarsinebalia cristoboi } \\
(\mathrm{C} / \mathrm{E})\end{array}$ & $\begin{array}{l}\text { Animoceradocus } \\
\text { semiserratus }(\mathrm{C} / \mathrm{I})\end{array}$ & Necallianassa truncata $(\mathrm{C} / \mathrm{P})$ & $\begin{array}{l}\text { Ampelisca } \\
\text { pseudosarsi } \\
(\mathrm{C} / \mathrm{I})\end{array}$ & Ampelisca typica (O/I) \\
\hline & $\begin{array}{l}\text { Perioculodes } \\
\text { longimanus (C/I) }\end{array}$ & $\begin{array}{l}\text { Eurydice naylori } \\
(\mathrm{C} / \mathrm{P})\end{array}$ & $\begin{array}{l}\text { Liocarcinus } \\
\text { navigator }(\mathrm{O} / \mathrm{E})\end{array}$ & Bathyporeia tenuipes $(\mathrm{O} / \mathrm{E})^{*}$ & $\begin{array}{l}\text { Astacilla } \\
\text { dilatata }(0 / \mathrm{P})\end{array}$ & Harpinia antennaria $(\mathrm{C} / \mathrm{I})$ \\
\hline & $\begin{array}{l}\text { Monoculodes } \\
\text { carinatus }(\mathrm{C} / \mathrm{I})\end{array}$ & $\begin{array}{l}\text { Megamphopus } \\
\text { cornutus (C/P) }\end{array}$ & $\begin{array}{l}\text { Ampithoe } \\
\text { gammaroides } \\
(\mathrm{R} / \mathrm{E})^{*}\end{array}$ & Megaluropus agilis (O/I) & $\begin{array}{l}\text { Ampelisca sp. } \\
(\mathrm{O} / \mathrm{P})\end{array}$ & $\begin{array}{l}\text { Goneplax rhomboides } \\
(\mathrm{R} / \mathrm{E})\end{array}$ \\
\hline & $\begin{array}{l}\text { Amphilochus } \\
\text { spencebatei } \\
(\mathrm{O} / \mathrm{P})\end{array}$ & $\begin{array}{l}\text { Apherusa bispinosa } \\
(\mathrm{C} / \mathrm{P})\end{array}$ & $\begin{array}{l}\text { Dexamine sp. } \\
(\mathrm{R} / \mathrm{E})^{*}\end{array}$ & Diastylis bradyi $(\mathrm{C} / \mathrm{I})$ & $\begin{array}{l}\text { Ampelisca } \\
\text { spinifer }(\mathrm{O} / \mathrm{P})\end{array}$ & Anapagurus laevis (O/I) \\
\hline & $\begin{array}{l}\text { Pontocrates } \\
\text { altamarinus }(\mathrm{O} / \mathrm{I})\end{array}$ & Leucothoe incisa $(\mathrm{C} / \mathrm{I})$ & $\begin{array}{l}\text { Xantho pilipes } \\
(\mathrm{R} / \mathrm{E})^{*}\end{array}$ & Leucothoe incisa (C/I) & $\begin{array}{l}\text { Apseudes talpa } \\
(\mathrm{C} / \mathrm{I})\end{array}$ & Gnathia oxyuraea (O/I) \\
\hline & $\begin{array}{l}\text { Haustorius } \\
\text { arenarius }(\mathrm{R} / \mathrm{E})^{*}\end{array}$ & $\begin{array}{l}\text { Haplostylus normani } \\
(\mathrm{C} / \mathrm{P})\end{array}$ & $\begin{array}{l}\text { Iphinoe tenella } \\
(\mathrm{R} / \mathrm{E})\end{array}$ & Ampelisca spinimana $(\mathrm{O} / \mathrm{P})$ & $\begin{array}{l}\text { Westwoodilla } \\
\text { caecula }(\mathrm{O} / \mathrm{I})\end{array}$ & $\begin{array}{l}\text { Ampelisca armoricana } \\
(\mathrm{O} / \mathrm{I})\end{array}$ \\
\hline & $\begin{array}{l}\text { Natatolana } \\
\text { gallica }(\mathrm{O} / \mathrm{I})\end{array}$ & $\begin{array}{l}\text { Galathea intermedia } \\
(\mathrm{C} / \mathrm{I})\end{array}$ & $\begin{array}{l}\text { Macropodia linaresi } \\
(\mathrm{R} / \mathrm{E})\end{array}$ & Bathyporeia elegans (R/E)* & $\begin{array}{l}\text { Erythrops } \\
\text { elegans }(\mathrm{R} / \mathrm{E})^{*}\end{array}$ & $\begin{array}{l}\text { Autonoe spiniventris } \\
\text { (C/A) }\end{array}$ \\
\hline & $\begin{array}{l}\text { Diogenes } \\
\text { pugilator (O/I) }\end{array}$ & $\begin{array}{l}\text { Leptocheirus } \\
\text { pectinatus }(\mathrm{C} / \mathrm{P})\end{array}$ & $\begin{array}{l}\text { Processa edulis } \\
\text { crassipes (R/E) }\end{array}$ & $\begin{array}{l}\text { Perioculodes longimanus } \\
\text { (C/I) }\end{array}$ & $\begin{array}{l}\text { Tmetonyx } \\
\text { similis }(\mathrm{R} / \mathrm{E})^{*}\end{array}$ & Diastylis bradyi $(\mathrm{O} / \mathrm{I})$ \\
\hline & $\begin{array}{l}\text { Liocarcinus } \\
\text { holsatus (R/P) }\end{array}$ & $\begin{array}{l}\text { Psammogammarus } \\
\text { caecus }(\mathrm{C} / \mathrm{I})\end{array}$ & $\begin{array}{l}\text { Ampelisca } \\
\text { pseudospinimana } \\
(\mathrm{R} / \mathrm{E})\end{array}$ & Pariambus typicus (O/I) & $\begin{array}{l}\text { Iphinoe serrata } \\
(\mathrm{O} / \mathrm{I})\end{array}$ & Urothoe elegans (R/P) \\
\hline & Astacilla sp. (R/P) & $\begin{array}{l}\text { Microjaera anisopoda } \\
(\mathrm{O} / \mathrm{E})^{*}\end{array}$ & $\begin{array}{l}\text { Semibalanus } \\
\text { balanoides (R/E) }\end{array}$ & $\begin{array}{l}\text { Hippomedon denticulatus } \\
(\mathrm{O} / \mathrm{I})\end{array}$ & $\begin{array}{l}\text { Ampelisca } \\
\text { provincialis } \\
(\mathrm{R} / \mathrm{P})\end{array}$ & Iphinoe trispinosa $(\mathrm{O} / \mathrm{I})$ \\
\hline & $\begin{array}{l}\text { Megaluropus } \\
\text { agilis }(\mathrm{O} / \mathrm{A})\end{array}$ & $\begin{array}{l}\text { Eurydice spinigera } \\
(\mathrm{O} / \mathrm{P})\end{array}$ & $\begin{array}{l}\text { Ampelisca verga } \\
(\mathrm{R} / \mathrm{P})\end{array}$ & Idunella longirostris $(\mathrm{R} / \mathrm{E})^{*}$ & $\begin{array}{l}\text { Ampelisca } \\
\text { remora }(\mathrm{R} / \mathrm{P})\end{array}$ & Alpheus glaber (O/I) \\
\hline & $\begin{array}{l}\text { Gastrosaccus } \\
\text { sanctus }(\mathrm{R} / \mathrm{I})\end{array}$ & $\begin{array}{l}\text { Socarnes } \\
\text { erythrophthalmus } \\
\text { (C/I) }\end{array}$ & $\begin{array}{l}\text { Thia scutellata } \\
(\mathrm{R} / \mathrm{P})\end{array}$ & Urothoe grimaldii $(0 / \mathrm{P})$ & $\begin{array}{l}\text { Idunella picta } \\
(\mathrm{R} / \mathrm{P})\end{array}$ & Eurynome spinosa $(\mathrm{R} / \mathrm{P})$ \\
\hline & $\begin{array}{l}\text { Gammaropsis } \\
\text { sophiae }(\mathrm{R} / \mathrm{I})\end{array}$ & $\begin{array}{l}\text { Caprella lilliput } \\
(\mathrm{O} / \mathrm{E})^{*}\end{array}$ & $\begin{array}{l}\text { Isaea montagui } \\
(\mathrm{R} / \mathrm{P})\end{array}$ & Abludomelita obtusata (R/P) & $\begin{array}{l}\text { Nebalia } \\
\text { troncosoi (R/P) }\end{array}$ & Kupellonura sp. (R/E)* \\
\hline
\end{tabular}

the total macrofauna species richness and abundance (Martins et al., 2013a and unpublished data). Similar species ratios were found in other studies in the Atlantic (Ellingsen and Gray, 2002; Martínez et al., 2007; Rees et al., 1999) and the Mediterranean (Karakassis and Eleftheriou, 1997) continental shelves with differences related to the sampling effort and accuracy of sampling protocols (Gentil and Dauvin, 1988). Higher crustacean abundance ratios have been reported elsewhere (e.g. Martínez et al., 2007), whereas polychaetes dominate in the Portuguese continental shelf (Martins et al., 2013a, 2013b). Furthermore, the ratio between crustacean plus mollusc species to annelids was 1.04 confirming the expected values for temperate areas (Reise, 1991), which was namely also reported for the Tagus basin, the largest Iberian estuary (Rodrigues et al., 2006). The diversity and/or the distribution of species among the various crustacean groups were similar to other North Atlantic large scale benthic studies (Brandt, 1995; Ellingsen et al., 2005; Lyubina et al., 2014; Stransky and Brandt, 2010). Moreover, the percentage of rare species was comparable to similar diversity studies (Aslan-Cihangir and Pancucci-Papadopoulou, 2011; Ellingsen and Gray, 2002; Moulaert et al., 2007). Overall, nearly $90 \%$ of the Portuguese crustacean fauna found in this study has also been recorded in the British, French, Spanish or Mediterranean faunas, while an overlap with the Macaronesian/West African fauna approaching $70 \%$ (Table 4 ). Over $60 \%$ of the species here reported are shared by all the mentioned faunas when considered together and this percentage rises to $80 \%$ when only North Atlantic and Mediterranean are involved (Table 4). This confirmed the Atlantic-Mediterranean status of the Portuguese amphipod fauna denoted by Marques and Bellan-Santini (1991), but also revealed a noticeable subtropical influence. Previously, 
Table 3

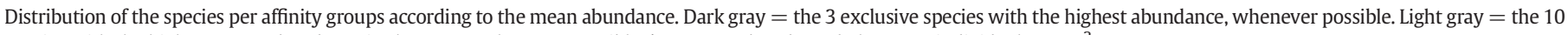
species with the highest mean abundance in the group, whenever possible. ${ }^{*}=$ Mean abundance below 0.05 individuals $/ 0.1 \mathrm{~m}^{2}$.

\begin{tabular}{|c|c|c|c|c|c|c|}
\hline Species & A & B1 & B2 & C1 & C2 & C3 \\
\hline Haustorius arenarius (Slabber, 1769) & 0.1 & & & & & \\
\hline Gastrosaccus spinifer (Goës, 1864) & 46.0 & 2.3 & & 0.2 & & * \\
\hline Gastrosaccus sanctus (Van Beneden, 1861) & 7.1 & 0.1 & & $*$ & & * \\
\hline Nototropis falcatus (Metzger, 1871) & 1.3 & $*$ & & 0.1 & & \\
\hline Pontocrates arenarius (Bate, 1858) & 1.0 & 0.3 & 0.2 & 0.1 & & \\
\hline Perioculodes longimanus (Bate and Westwood, 1868) & 0.9 & 0.2 & & 0.5 & 0.1 & * \\
\hline Monoculodes carinatus (Bate, 1857) & 0.7 & 0.3 & & & & * \\
\hline Pontocrates altamarinus (Bate and Westwood, 1862) & 0.6 & 0.1 & & 0.1 & & \\
\hline Diogenes pugilator (Roux, 1829) & 0.5 & & & 0.4 & & * \\
\hline Caprella lilliput Krapp-Schickel and Ruffo, 1987 & & 1.2 & & & & \\
\hline Orchomene similis (Chevreux, 1912) & & 0.5 & & & & \\
\hline Tryphosella sarsi Bonnier, 1893 & & 0.4 & & & & \\
\hline Socarnes erythrophthalmus Robertson, 1892 & 0.1 & 5.4 & & 0.3 & & * \\
\hline Cheirocratus sundevallii (Rathke, 1843) & 0.1 & 5.2 & 0.1 & $*$ & & * \\
\hline Apherusa bispinosa (Bate, 1857) & & 4.1 & & 0.2 & & \\
\hline Sarsinebalia cristoboi Moreira, Gestoso and Troncoso, 2003 & & 3.8 & & 0.1 & & * \\
\hline Othomaera othonis (Milne-Edwards, 1830) & & 3.6 & 3.4 & 0.4 & 0.9 & 0.2 \\
\hline Haplostylus normani (Sars G.O., 1877) & 0.2 & 3.4 & & 0.1 & & 0.1 \\
\hline Guernea (Guernea) coalita (Norman, 1868) & 0.1 & 2.9 & & $*$ & & $*$ \\
\hline Galathea intermedia Liljeborg, 1851 & & 2.6 & 0.1 & * & & 0.2 \\
\hline Ampithoe gammaroides (Bate, 1856) & & & 0.1 & & & \\
\hline Dexamine sp. Leach, 1814 & & & 0.1 & & & \\
\hline Xantho pilipes A. Milne-Edwards, 1867 & & & 0.1 & & & \\
\hline Animoceradocus semiserratus (Bate, 1862) & & 0,9 & 1.3 & & & 0.1 \\
\hline Processa modica modica Williamson in Williamson and Rochanaburanon, 1979 & 0.1 & * & 0.4 & * & & * \\
\hline Liocarcinus navigator (Herbst, 1794) & & & 0.4 & & & * \\
\hline Phtisica marina Slabber, 1769 & & * & 0.3 & 0.1 & & 0.1 \\
\hline Alpheus glaber (Olivi, 1792) & & & 0.2 & $*$ & & 0.2 \\
\hline Ampelisca pseudospinimana Bellan-Santini and Kaim-Malka, 1977 & & * & 0.2 & & & \\
\hline Processa edulis crassipes Nouvel andHolthuis, 1957 & & & 0.2 & & & * \\
\hline Bathyporeia tenuipes Meinert, 1877 & & & & 0.4 & & \\
\hline Bathyporeia elegans Watkin, 1938 & & & & 0.3 & & \\
\hline Bathyporeia gracillis Sars, 1891 & & & & 0.3 & & \\
\hline Ampelisca brevicornis (Costa, 1853) & & * & 0.4 & 4.4 & 1.0 & 0.3 \\
\hline Urothoe pulchella (Costa, 1853) & & & 0.3 & 2.7 & & \\
\hline Necallianassa truncata (Giard andBonnier, 1890) & & * & & 2.0 & & 0.2 \\
\hline Diastylis bradyi Norman, 1879 & & $*$ & & 1.7 & & 0.3 \\
\hline Leucothoe incisa (Robertson, 1892) & & 0.9 & & 1.4 & & * \\
\hline Bodotria scorpioides (Montagu, 1804) & & $*$ & & 1.3 & 0.8 & 0.1 \\
\hline Pariambus typicus (Krøyer, 1884) & 0.1 & 0.7 & & 1.3 & & * \\
\hline Ampelisca spinimana Chevreux, 1900 & & & & 1.3 & & * \\
\hline Megaluropus agilis Hoeck, 1889 & 0.5 & * & & 0.6 & & * \\
\hline Erythrops elegans (Sars G.O., 1863) & & & & & 0.1 & \\
\hline Tmetonyx similis (Sars, 1891) & & & & & 0.1 & \\
\hline Ampelisca pectenata Reid, 1951 & & $*$ & & 0.1 & 1.2 & 0.2 \\
\hline Ampelisca pseudosarsi Bellan-Santini and Kaim-Malka, 1977 & & * & & 0.1 & 0.7 & 0.1 \\
\hline Ampelisca provincialis Bellan-Santini andKaim-Malka, 1977 & & & & & 0.4 & $*$ \\
\hline Cirolana cranchii Leach, 1818 & & & & & & 0.1 \\
\hline \multicolumn{6}{|l|}{ Kupellonura sp. Barnard, 1925} & 0.1 \\
\hline \multicolumn{7}{|l|}{ Ericthonius punctatus (Bate, 1857) } \\
\hline Ampelisca tenuicornis Liljeborg, 1855 & & & & 0.1 & 0.3 & 1.6 \\
\hline Apseudes talpa (Montagu, 1808) & & * & 0.2 & & 0.6 & 0.9 \\
\hline Harpinia antennaria Meinert, 1890 & 0.1 & 0.1 & 0.1 & 0.3 & 0.3 & 0.8 \\
\hline Callianassa subterranea (Montagu, 1808) & & & & 0.2 & & 0.6 \\
\hline Ampelisca armoricana Bellan-Santini and Dauvin, 1981 & & $*$ & & 0.5 & 0.1 & 0.6 \\
\hline Autonoe spiniventris Della Valle, 1893 & & 0.4 & 0.4 & 0.4 & 0.1 & 0.5 \\
\hline Ampelisca spinipes Boeck, 1861 & & 0.4 & & 0.3 & 0.2 & 0.5 \\
\hline Ampelisca typica (Bate, 1856) & & $*$ & & 0.5 & & 0.5 \\
\hline Anapagurus laevis (Bell, 1846) & 0.2 & 0.1 & & $*$ & 0.2 & 0.3 \\
\hline
\end{tabular}


Cunha et al. (1997) reported, off Aveiro, about 80\% resemblance to the northern Atlantic species of amphipods, cumaceans and decapods, which is now nearly $10 \%$ higher. The ongoing update of the crustacean checklists by new taxonomy studies and reviews contribute to enhance this resemblance. Nevertheless, the species found in this study comprise just $6 \%$ of the 4150 known north Atlantic and Mediterranean crustacean species collected from the intertidal to the deep sea (Costello et al., 2006).

Most of the species sampled in this study were previously recorded in the Portuguese shelf (Cunha et al., 1997; Freitas et al., 2011; Marques, 1989; Marques and Bellan-Santini, 1991, 1993; Martins et al., 2013a). This study confirmed the first record for the Portuguese coast of the amphipods Dulichia sp., Medicorophium minimum, Megamphopus brevidactylus and Normanion sarsi, and the cumaceans Diastyloides serratus and Eocuma dimorphum stated by Martins et al. (2013a). Diastyloides serratus and E. dimorphum distribution extends from France to West Africa and includes now the Portuguese coast. For the Mediterranean species $M$. minimum and $M$. brevidactylus, the northwestern limit is now set in the southern Portuguese coast, the Algarve. The North Atlantic amphipods Dulichia sp. and N. sarsi have now the southern limit set off Aveiro (Costa de Prata) and the Nazaré Canyon, respectively.

Acidostoma obesum, Ampelisca verga, A. spiniventris, Caprella lilliput, Harpinia truncata, Idunella excavata, Melita cf. valesi, Metopella sp., Orchemene similis and Pseudolirius kroyeri (amphipoda), Michelopagurus atlanticus (decapoda), A. dilatata, Cortezura sp., Gnathia oxyuracea, Kupellonura sp. and Microjaera anisopoda (isopoda), Nebalia troncosoi, S. cristoboi and Sarsinebalia urgorii (leptostraca) are 19 new records for the Portuguese coast. From these, the amphipods A. obesum, A. spiniventris, $H$. truncata, Orchomene similis and $P$. kroyeri and the isopods A. dilatata, G. oxyuracea and M. anisopoda have previously been reported for the Mediterranean and the Atlantic Spanish and/or French coasts (Bachelet et al., 2003; Bellan-Santini et al., 1982, 1989, 1993; Dauvin and Bellan-Santini, 2002; Junoy and Castelló, 2003; Vanquickelberghe, 2004) and are now also reported for the Portuguese continental shelf area, filling this gap in their distributions.

For some species, this study expanded their reported distribution range to northern latitudes, namely the amphipods $C$. lilliput and Inquilina excavata, previously considered endemic to the Mediterranean (Bellan-Santini et al., 1989, 1993) but found here off Aveiro (Costa de Prata). Another endemic, $M$. cf. valesi, reported here for the first time outside the Mediterranean, was collected off Vila do Conde (Costa Verde). However, this finding must be viewed with caution since there are slight differences from the type species, especially in the antennae morphology (antenna 1 peduncle article 1 reaches the end of antenna 2 peduncle article 4 ) and in the uropod spines thickness (BellanSantini et al., 1982). The isopod Kupellonura sp. found in this study in the western coast off Peniche and in the southern coast is also distinct from the Mediterranean species $K$. flexibilis reported from the Baleares islands (Junoy and Castelló, 2003). Ferreira (2009) reported a Kupellonura sp. from the Nazaré Cannyon but it remains to determine if it is the same species as reported here. The Western African amphipod $A$. verga, a species originally described as a variety of Ampelisca aequicornis by Reid (1951) off Dakar, Senegal, and later confirmed as a true species (Dauvin and Bellan-Santini, 1985) is here firstly recorded in the Algarve coast, the northmost known location.

Anapagurus pusillus and M. atlanticus (Decapoda) originally described for the Azores have now extended their distribution eastwards. Anapagurus pusillus was first reported outside the Azores in the Algarve coast (cf. Ingle, 1993 and references therein) while this study establishes a new northeastern limit for the species off Figueira da Foz, Costa de Prata. Moreover, M. atlanticus was found off Aveiro, Costa de Prata, in shallow depth $(41 \mathrm{~m})$, previously reported at $1250 \mathrm{~m}$ in the Azores (cf. Ingle, 1993 and references therein). The isopod Cortezura sp., a genus reported to Venezuela and North America (Poore and Schotte, 2015), was found in this study off Aveiro, Setúbal, Sines and in the Algarve coast and was identified using the key provided by Poore (2001).

Some boreal species like the amphipod Metopella sp. and the cumacean Brachydiastylis resima are first records for the Portuguese coast and have established a new southern limit off Figueira da Foz and Marinha Grande (Costa de Prata), respectively. Species from cold waters (e.g. Apherusa cirrus, Argissa hamatipes; Marques, 1989) are usually also found off the Portuguese coast due to upwelling events (López-Jamar et al., 1992; Nascimento et al., 2012; Ospina-Alvarez et al., 2010). However, Metopella sp. reported in this study is distinct from M. nasuta reported in British waters by Lincoln (1979) but it is distinguishable from other Sthenothoidae by their narrowed pereopod 6-7 basis. This study also confirmed a new southern limit for the leptostracans N. troncosoi (off Figueira da Foz, Costa de Prata), S. cristoboi (off Aljezur, Algarve) and S. urgorii (off Aveiro, Costa de Prata), formerly ascribed to Galiza, Spain (Moreira et al., 2009).

\subsection{Benthic crustacea communities}

Soft bottom Atlantic and Mediterranean benthic communities were described by Glémarec (1973); Pérès and Picard (1964), and Thorson (1957), among others. The coarse sands assemblage described in this study (group A) can be linked to the biocoenosis of coarse sands and fine gravels under swell influence identified by Pérès and Picard (1964) in the Mediterranean. This assemblage is characterized by a great abundance of the mysid G. spinifer and a low species richness reflecting the shallow water high energy environment. Freitas et al. (2003) reported a very similar assemblage in the shallow waters off Aveiro, populated by G. spinifer and $N$. falcatus, and in the north of Spain a similar group, characterized by G. spinifer as constant and elective species, was associated to medium sands in Ría de Aldán (Lourido et al., 2008).

The very coarse sands described here (group B1) shared some species with the previous assemblage but were mainly characterized by the highest species richness among all the affinity groups. This assemblage has a good correspondence with the biocoenosis of coarse sands and fine gravels under the influence of bottom currents identified in the Mediterranean by Pérès and Picard (1964) and the Branchiostoma lanceolatus-Venus fasciata community recognized in European coasts (Thorson, 1957). Guernea (Guernea) coalita, S. erythrophthalmus, Haplostylus sp. and Eurydice sp. were also encountered among the coarse sandy sediments in Ría de Aldán (Lourido et al., 2008). Martins and co-workers were unable to separate these two assemblages, when considering the whole macrofauna (Martins et al., 2013a), or the assemblages defined by annelids or molluscs alone (Martins et al., 2013b, 2014), surely due to a much smaller sampling effort than that here considered.

The heterogeneous medium sands assemblage (group B2) was quite different from the two previous affinity groups and characterized by low richness and the dominance of decapod species. This assemblage was observed in deeper waters and has no close resemblance with other Atlantic and Mediterranean communities but shares a few species, namely 0 . othonis, Dexamine sp. and other related decapods, with the maërl bottom communities described by Jacquotte (1962) and to some extent resembles the biocoenosis of coastal detritic bottoms defined by Pérès and Picard (1964). This crustacean community is accompanied by some non-crustacean species recognized in the macrofauna southern muddy sand community (Martins et al., 2013a) and the polychaete southern shelf assemblage (Martins et al., 2013b).

The fine sands assemblage (group C1), characterized by $A$. brevicornis and $U$. pulchella, corresponds to the Venus gallina community (Thorson, 1957), the fine sands with V. gallina and Mactra corallina in the infralittoral of the North Gascony continental shelf (Glémarec, 1973 ) or the well sorted fine sands biocenosis in French Mediterranean (Pérès and Picard, 1964). A similar community was documented in Freitas et al. (2006); Quintino et al. (2001) and Reis et al. (1982). 

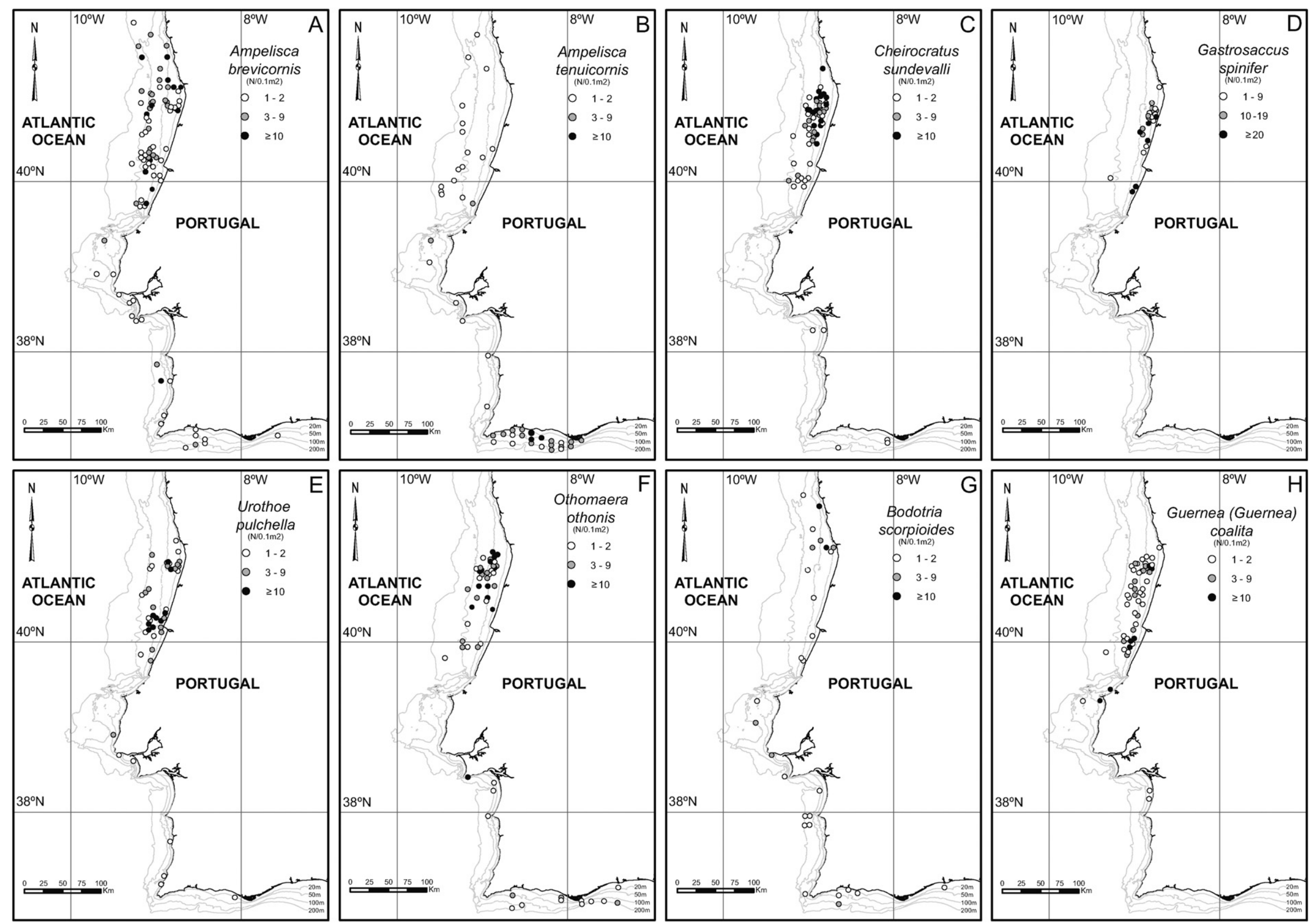

Fig. 5. Abundance distribution patterns of selected crustacean species in the Portuguese continental shelf 
Table 4

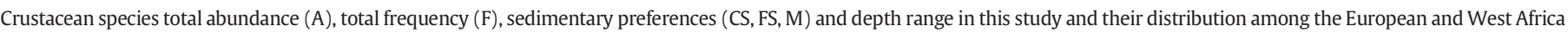

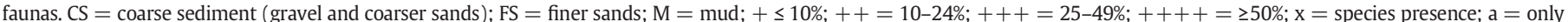

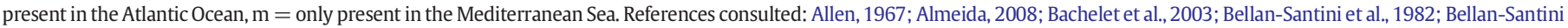

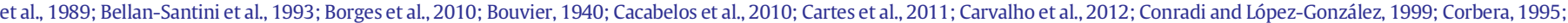

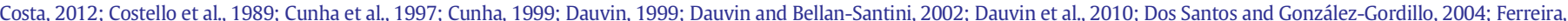

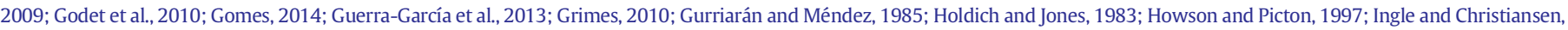

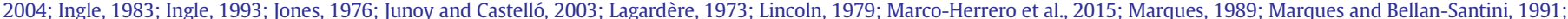

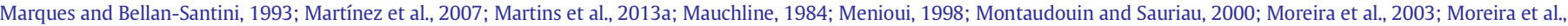

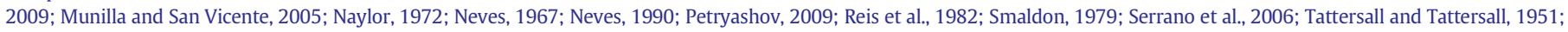
Udekem d'Acoz, 1999; Vanquickelberghe, 2004; Zariquiey Alvarez, 1968.

\begin{tabular}{|c|c|c|c|c|c|c|c|c|c|c|c|c|}
\hline \multirow[t]{2}{*}{ Species } & \multicolumn{6}{|c|}{ This study } & \multicolumn{6}{|l|}{ Literature } \\
\hline & A & $\mathrm{F}$ & CS & FS & M & $\begin{array}{l}\text { Depth } \\
\text { range } \\
\text { (meters) }\end{array}$ & Portugal & Britain & France & Spain & Mediterranean & $\begin{array}{l}\text { West Africa } \\
\text { and } \\
\text { Macaronesia }\end{array}$ \\
\hline \multicolumn{13}{|l|}{ Amphipoda } \\
\hline Abludomelita gladiosa (Bate, 1862) & 11 & 3 & ++++ & & & $46-70$ & $\mathrm{x}$ & $\mathrm{x}$ & $\mathrm{x}$ & $\mathrm{x}(\mathrm{m})$ & $\mathrm{x}$ & $\mathrm{x}$ \\
\hline Abludomelita obtusata (Montagu, 1813) & 15 & 9 & ++ & ++++ & & $23-55$ & $\mathrm{x}$ & $\mathrm{x}$ & $\mathrm{x}$ & $\mathrm{x}$ & $\mathrm{x}$ & $\mathrm{x}$ \\
\hline Acidostoma obesum (Bate \& Westwood, 1861) & 2 & 1 & & ++++ & & 48 & & $\mathrm{x}$ & $\mathrm{x}$ & $\mathrm{x}$ & $\mathrm{x}$ & \\
\hline $\begin{array}{l}\text { Ampelisca armoricana Bellan-Santini \& Dauvin, } \\
1981\end{array}$ & 106 & 36 & ++ & ++++ & ++ & $16-145$ & $\mathrm{x}$ & $\mathrm{x}$ & $x(a)$ & $x(a)$ & & $\mathrm{x}$ \\
\hline Ampelisca brevicornis (Costa, 1853) & 429 & 86 & ++ & ++++ & + & $17-190$ & $\mathrm{x}$ & $\mathrm{x}$ & $\mathrm{x}$ & $\mathrm{x}$ & $\mathrm{x}$ & $\mathrm{x}$ \\
\hline $\begin{array}{l}\text { Ampelisca calypsonis Bellan-Santini \& } \\
\quad \text { Kaim-Malka, } 1977\end{array}$ & 7 & 5 & +++ & ++++ & & $49-168$ & $\mathrm{x}$ & & & & $\mathrm{x}$ & \\
\hline Ampelisca dalmatina Karaman, 1975 & 12 & 7 & ++++ & ++ & ++ & $53-103$ & $\mathrm{x}$ & $\mathrm{x}$ & $\mathrm{x}(\mathrm{m})$ & $\mathrm{x}(\mathrm{m})$ & $\mathrm{x}$ & \\
\hline Ampelisca diadema (Costa, 1853) & 9 & 9 & ++ & ++++ & ++ & $31-126$ & $\mathrm{x}$ & $\mathrm{x}$ & $\mathrm{x}$ & $\mathrm{x}$ & $\mathrm{x}$ & $\mathrm{x}$ \\
\hline Ampelisca heterodactyla Schellenberg, 1925 & 13 & 4 & +++ & ++++ & & $38-58$ & $\mathrm{x}$ & $\mathrm{x}$ & & $\mathrm{x}(\mathrm{a})$ & & \\
\hline Ampelisca pectenata Reid, 1951 & 37 & 21 & ++ & ++++ & & $46-182$ & $\mathrm{x}$ & $\mathrm{x}$ & $\mathrm{x}(\mathrm{a})$ & $x(a)$ & & \\
\hline $\begin{array}{l}\text { Ampelisca provincialis Bellan-Santini \& } \\
\text { Kaim-Malka, } 1977\end{array}$ & 8 & 3 & +++ & +++ & +++ & $26-53$ & $\mathrm{x}$ & $\mathrm{x}$ & & & $\mathrm{x}$ & \\
\hline $\begin{array}{l}\text { Ampelisca pseudosarsi Bellan-Santini \& } \\
\text { Kaim-Malka, } 1977\end{array}$ & 29 & 17 & ++ & ++++ & & $26-140$ & $\mathrm{x}$ & & & & $\mathrm{x}$ & \\
\hline $\begin{array}{l}\text { Ampelisca pseudospinimana Bellan-Santini \& } \\
\text { Kaim-Malka, } 1977\end{array}$ & 3 & 2 & ++++ & & & $16-25$ & $\mathrm{x}$ & & $\mathrm{x}(\mathrm{m})$ & & $\mathrm{x}$ & \\
\hline Ampelisca remora Bellan-Santini \& Dauvin, 1986 & 6 & 4 & +++ & ++++ & +++ & $26-99$ & $\mathrm{x}$ & & & $\mathrm{x}(\mathrm{a})$ & & \\
\hline $\begin{array}{l}\text { Ampelisca ruffoi Bellan-Santini \& Kaim-Malka, } \\
1977\end{array}$ & 39 & 19 & & ++++ & ++ & $97-136$ & $\mathrm{x}$ & & $\mathrm{x}(\mathrm{m})$ & & $\mathrm{x}$ & \\
\hline Ampelisca sarsi Chevreux, 1888 & 10 & 8 & & ++++ & & $17-117$ & $\mathrm{x}$ & $\mathrm{x}$ & $\mathrm{x}$ & $\mathrm{x}$ & $\mathrm{x}$ & $\mathrm{x}$ \\
\hline Ampelisca spinifer Reid, 1951 & 15 & 10 & & ++++ & ++ & $53-147$ & $\mathrm{x}$ & $\mathrm{x}$ & $\mathrm{x}$ & $\mathrm{x}$ & $\mathrm{x}$ & $\mathrm{x}$ \\
\hline Ampelisca spinimana Chevreux, 1900 & 124 & 20 & ++ & ++++ & +++ & $23-118$ & $\mathrm{x}$ & & $\mathrm{x}$ & $\mathrm{x}$ & $\mathrm{x}$ & $\mathrm{x}$ \\
\hline Ampelisca spinipes Boeck, 1861 & 112 & 48 & ++++ & +++ & + & $26-179$ & $\mathrm{x}$ & $\mathrm{x}$ & $\mathrm{x}$ & $\mathrm{x}$ & $\mathrm{x}$ & $\mathrm{x}$ \\
\hline Ampelisca tenuicornis Liljeborg, 1855 & 172 & 45 & ++ & ++++ & ++ & $24-190$ & $\mathrm{x}$ & $\mathrm{x}$ & $\mathrm{x}$ & $\mathrm{x}$ & $\mathrm{x}$ & $\mathrm{x}$ \\
\hline Ampelisca typica Bate, 1856 & 92 & 40 & ++ & ++++ & +++ & $16-174$ & $\mathrm{x}$ & $\mathrm{x}$ & $\mathrm{x}$ & $\mathrm{x}$ & $\mathrm{x}$ & $\mathrm{x}$ \\
\hline Ampelisca verga Reid, 1951 & 4 & 3 & ++++ & +++ & & $25-94$ & & & & & & $\mathrm{x}$ \\
\hline Amphilochus spencebatei (Stebbing, 1876) & 4 & 4 & ++++ & +++ & & $27-38$ & $\mathrm{x}$ & $\mathrm{x}$ & $\mathrm{x}$ & $\mathrm{x}$ & $\mathrm{x}$ & $\mathrm{x}$ \\
\hline Ampithoe gammaroides (Bate, 1856) & 1 & 1 & & ++++ & & 100 & $\mathrm{x}$ & $\mathrm{x}$ & $\mathrm{x}$ & $\mathrm{x}$ & $\mathrm{x}$ & $\mathrm{x}$ \\
\hline Animoceradocus semiserratus (Bate, 1862) & 111 & 28 & ++++ & & + & $25-159$ & $\mathrm{x}$ & $\mathrm{x}$ & $\mathrm{x}$ & $\mathrm{x}$ & $\mathrm{x}$ & \\
\hline Aora spinicornis Afonso, 1976 & 9 & 5 & ++++ & ++ & & $45-69$ & $\mathrm{x}$ & $\mathrm{x}$ & $\mathrm{x}$ & $\mathrm{x}$ & $\mathrm{x}$ & $\mathrm{x}$ \\
\hline Apherusa bispinosa (Bate, 1857) & 396 & 41 & ++++ & ++ & + & $33-103$ & $\mathrm{x}$ & $\mathrm{x}$ & $\mathrm{x}$ & $\mathrm{x}$ & $\mathrm{x}$ & $\mathrm{x}$ \\
\hline Apherusa cirrus (Bate, 1862) & 1 & 1 & ++++ & & & 48 & $\mathrm{x}$ & $\mathrm{x}$ & $\mathrm{x}(\mathrm{a})$ & & & \\
\hline Apherusa jurinei Milne-Edwards, 1830 & 12 & 7 & ++++ & & & $37-76$ & $\mathrm{x}$ & $\mathrm{x}$ & $\mathrm{x}$ & $\mathrm{x}$ & $\mathrm{x}$ & $\mathrm{x}$ \\
\hline Apolochus neapolitanus (Della Valle, 1893) & 3 & 2 & ++++ & ++++ & & $33-37$ & $\mathrm{x}$ & $\mathrm{x}$ & $\mathrm{x}$ & $\mathrm{x}$ & $\mathrm{x}$ & $\mathrm{x}$ \\
\hline Argissa hamatipes (Norman, 1869) & 8 & 7 & ++++ & +++ & & $23-62$ & $\mathrm{x}$ & $\mathrm{x}$ & $\mathrm{x}$ & $\mathrm{x}$ & $\mathrm{x}$ & $\mathrm{x}$ \\
\hline Atylus vedlomensis (Bate \& Westwood, 1862) & 73 & 34 & ++++ & ++ & + & $14-190$ & $\mathrm{x}$ & $\mathrm{x}$ & $\mathrm{x}$ & $\mathrm{x}$ & $\mathrm{x}$ & $\mathrm{x}$ \\
\hline Autonoe spiniventris Della Valle, 1893 & 124 & 67 & +++ & +++ & + & $16-195$ & & & $\mathrm{x}$ & $\mathrm{x}$ & $\mathrm{x}$ & \\
\hline Bathyporeia elegans Watkin, 1938 & 26 & 10 & ++ & ++++ & & $25-69$ & $\mathrm{x}$ & $\mathrm{x}$ & $\mathrm{x}(\mathrm{a})$ & $\mathrm{x}(\mathrm{a})$ & & $\mathrm{x}$ \\
\hline Bathyporeia gracilis Sars, 1891 & 25 & 5 & ++ & ++++ & & $38-50$ & $\mathrm{x}$ & $\mathrm{x}$ & $\mathrm{x}(\mathrm{a})$ & & & \\
\hline Bathyporeia guilliamsoniana (Bate, 1857) & 9 & 4 & & ++++ & & $21-26$ & $\mathrm{x}$ & $\mathrm{x}$ & $\mathrm{x}$ & $\mathrm{x}$ & $\mathrm{x}$ & $\mathrm{x}$ \\
\hline Bathyporeia nana Toulmond, 1966 & 1 & 1 & & ++++ & & 25 & $\mathrm{x}$ & $\mathrm{x}$ & $\mathrm{x}$ & $\mathrm{x}$ & $\mathrm{x}$ & \\
\hline Bathyporeia pelagica (Bate, 1856) & 9 & 1 & & ++++ & & 41 & $\mathrm{x}$ & $\mathrm{x}$ & $\mathrm{x}(\mathrm{a})$ & $\mathrm{x}(\mathrm{a})$ & & $\mathrm{x}$ \\
\hline Bathyporeia pilosa Lindström, 1855 & 7 & 1 & & ++++ & & 26 & $\mathrm{x}$ & $\mathrm{x}$ & $\mathrm{x}$ & $\mathrm{x}$ & $\mathrm{x}$ & $\mathrm{x}$ \\
\hline Bathyporeia sarsi Watkin, 1938 & 19 & 8 & & ++++ & & $17-69$ & $\mathrm{x}$ & $\mathrm{x}$ & $\mathrm{x}$ & $\mathrm{x}$ & $\mathrm{x}$ & \\
\hline Bathyporeia tenuipes Meinert, 1877 & 36 & 17 & + & ++++ & & $21-91$ & $\mathrm{x}$ & $\mathrm{x}$ & $\mathrm{x}(\mathrm{a})$ & $\mathrm{x}(\mathrm{a})$ & & \\
\hline Caprella lilliput Krapp-Schickel \& Ruffo, 1987 & 111 & 15 & ++++ & & & $33-85$ & $\mathrm{x}$ & & & & $\mathrm{x}$ & \\
\hline Caprella penantis Leach, 1814 & 1 & 1 & ++++ & & & 53 & $\mathrm{x}$ & $\mathrm{x}$ & $\mathrm{x}$ & $\mathrm{x}$ & $\mathrm{x}$ & $\mathrm{x}$ \\
\hline Cheirocratus assimilis (Lilljeborg, 1852) & 6 & 2 & ++++ & & & $69-87$ & $\mathrm{x}$ & $\mathrm{x}$ & $\mathrm{x}$ & & $\mathrm{x}$ & \\
\hline Cheirocratus sundevallii (Rathke, 1843) & 486 & 60 & ++++ & + & & $34-179$ & $\mathrm{x}$ & $\mathrm{x}$ & $\mathrm{x}$ & $\mathrm{x}$ & $\mathrm{x}$ & \\
\hline Deflexilodes subnudus (Norman, 1889) & 1 & 1 & & ++++ & & 48 & $\mathrm{x}$ & $\mathrm{x}$ & $\mathrm{x}$ & & $\mathrm{x}$ & \\
\hline Dexamine sp. Leach, 1814 & 1 & 1 & & & ++++ & 148 & $\mathrm{x}$ & $\mathrm{x}$ & $\mathrm{x}$ & $\mathrm{x}$ & $\mathrm{x}$ & $\mathrm{x}$ \\
\hline Dulichia sp. Krøyer, 1845 & 3 & 2 & ++++ & & & $45-69$ & $\mathrm{x}$ & $\mathrm{x}$ & & & & \\
\hline Ericthonius punctatus (Bate, 1857) & 5 & 1 & & & ++++ & 129 & $\mathrm{x}$ & $\mathrm{x}$ & $\mathrm{x}$ & $\mathrm{x}$ & $\mathrm{x}$ & $\mathrm{x}$ \\
\hline Eusirus longipes Boeck, 1861 & 2 & 2 & & ++++ & ++++ & $93-133$ & $\mathrm{x}$ & $\mathrm{x}$ & $\mathrm{x}$ & $\mathrm{x}$ & $\mathrm{x}$ & $\mathrm{x}$ \\
\hline Gammarella fucicola (Leach, 1814) & 23 & 5 & ++++ & ++ & & $49-84$ & $\mathrm{x}$ & $\mathrm{x}$ & $\mathrm{x}$ & $\mathrm{x}$ & $\mathrm{x}$ & $\mathrm{x}$ \\
\hline Gammaropsis maculata (Johnston, 1828) & 24 & 13 & ++++ & ++ & & $25-91$ & $\mathrm{x}$ & $\mathrm{x}$ & $\mathrm{x}$ & $\mathrm{x}$ & $\mathrm{x}$ & $\mathrm{x}$ \\
\hline Gammaropsis nitida (Stimpson, 1853) & 1 & 1 & ++++ & & & 45 & $\mathrm{x}$ & $\mathrm{x}$ & $\mathrm{x}(\mathrm{a})$ & & & \\
\hline Gammaropsis sophiae (Boeck, 1861) & 10 & 7 & +++ & ++++ & & $37-74$ & $\mathrm{x}$ & $\mathrm{x}$ & $\mathrm{x}$ & $\mathrm{x}$ & $\mathrm{x}$ & $\mathrm{x}$ \\
\hline Guernea (Guernea) coalita (Norman, 1868) & 276 & 53 & ++++ & + & & $23-122$ & $\mathrm{x}$ & $\mathrm{x}$ & $\mathrm{x}$ & $\mathrm{x}$ & $\mathrm{x}$ & $\mathrm{x}$ \\
\hline
\end{tabular}


Table 4 (continued)

\begin{tabular}{|c|c|c|c|c|c|c|c|c|c|c|c|c|}
\hline \multirow[t]{2}{*}{ Species } & \multicolumn{6}{|c|}{ This study } & \multicolumn{6}{|l|}{ Literature } \\
\hline & A & $\mathrm{F}$ & CS & FS & M & $\begin{array}{l}\text { Depth } \\
\text { range } \\
\text { (meters) }\end{array}$ & Portugal & Britain & France & Spain & Mediterranean & $\begin{array}{l}\text { West Africa } \\
\text { and } \\
\text { Macaronesia }\end{array}$ \\
\hline Harpinia antennaria Meinert, 1890 & 119 & 46 & ++ & ++++ & +++ & $29-174$ & $\mathrm{x}$ & $\mathrm{x}$ & $\mathrm{x}$ & $\mathrm{x}$ & $\mathrm{x}$ & $\mathrm{x}$ \\
\hline Harpinia pectinata Sars, 1891 & 19 & 9 & & +++ & ++++ & $33-130$ & $\mathrm{x}$ & $\mathrm{x}$ & $\mathrm{x}$ & $\mathrm{x}$ & $\mathrm{x}$ & $\mathrm{x}$ \\
\hline Harpinia truncata Sars, 1891 & 7 & 6 & +++ & ++++ & & $45-160$ & & $\mathrm{x}$ & $\mathrm{x}$ & $\mathrm{x}(\mathrm{m})$ & $\mathrm{x}$ & \\
\hline Haustorius arenarius (Slabber, 1769) & 1 & 1 & ++++ & & & 15 & $\mathrm{x}$ & $\mathrm{x}$ & $\mathrm{x}$ & $\mathrm{x}$ & $\mathrm{x}$ & $\mathrm{x}$ \\
\hline Hippomedon denticulatus (Bate, 1857) & 50 & 36 & +++ & ++++ & + & $17-144$ & $\mathrm{x}$ & $\mathrm{x}$ & $\mathrm{x}$ & $\mathrm{x}$ & $\mathrm{x}$ & $\mathrm{x}$ \\
\hline Hyperia sp. Latreille, 1823 & 3 & 3 & ++++ & & & $41-76$ & $\mathrm{x}$ & $\mathrm{x}$ & $\mathrm{x}$ & $\mathrm{x}$ & $\mathrm{x}$ & $\mathrm{x}$ \\
\hline Ichnopus spinicornis Boeck, 1861 & 1 & 1 & ++++ & & & 195 & $\mathrm{x}$ & $\mathrm{x}$ & $\mathrm{x}$ & $\mathrm{x}$ & $\mathrm{x}$ & $\mathrm{x}$ \\
\hline Idunella excavata (Schecke, 1973) & 31 & 8 & ++++ & & & $38-55$ & & & & & $\mathrm{x}$ & $\mathrm{x}$ \\
\hline Idunella longirostris (Chevreux, 1920) & 12 & 8 & & ++++ & & $21-33$ & $\mathrm{x}$ & $\mathrm{x}$ & $\mathrm{x}(\mathrm{a})$ & $\mathrm{x}(\mathrm{a})$ & & \\
\hline Idunella picta (Norman, 1889) & 7 & 4 & ++++ & ++++ & & $38-103$ & $\mathrm{x}$ & $\mathrm{x}$ & $\mathrm{x}$ & $\mathrm{x}$ & $\mathrm{x}$ & $\mathrm{x}$ \\
\hline Iphimedia minuta G.O. Sars, 1882 & 1 & 1 & & ++++ & & 52 & $\mathrm{x}$ & $\mathrm{x}$ & $\mathrm{x}$ & $\mathrm{x}(\mathrm{m})$ & $\mathrm{x}$ & $\mathrm{x}$ \\
\hline Isaea montagui Milne-Edwards, 1830 & 6 & 5 & ++++ & & ++ & $66-195$ & $\mathrm{x}$ & $\mathrm{x}$ & $\mathrm{x}$ & & $\mathrm{x}$ & \\
\hline Jassa falcata (Montagu, 1808) & 6 & 5 & ++++ & ++ & & $53-106$ & $\mathrm{x}$ & $\mathrm{x}$ & $\mathrm{x}$ & $\mathrm{x}$ & $\mathrm{x}$ & $\mathrm{x}$ \\
\hline $\begin{array}{l}\text { Lepidepecreum longicornis (Bate \& Westwood, } \\
1862 \text { ) }\end{array}$ & 5 & 3 & ++++ & +++ & & $37-50$ & $\mathrm{x}$ & $\mathrm{x}$ & $\mathrm{x}$ & $\mathrm{x}$ & $\mathrm{x}$ & $\mathrm{x}$ \\
\hline Leptocheirus hirsutimanus (Bate, 1862) & 71 & 16 & ++++ & + & & $16-103$ & $\mathrm{x}$ & $\mathrm{x}$ & $\mathrm{x}$ & $\mathrm{x}(\mathrm{m})$ & $\mathrm{x}$ & \\
\hline Leptocheirus pectinatus (Norman, 1869) & 89 & 30 & ++++ & ++ & & $25-122$ & $\mathrm{x}$ & $\mathrm{x}$ & $\mathrm{x}$ & $\mathrm{x}(\mathrm{m})$ & $\mathrm{x}$ & $\mathrm{x}$ \\
\hline Leptocheirus tricristatus (Chevreux, 1887) & 7 & 6 & ++++ & ++++ & & $33-85$ & $\mathrm{x}$ & $\mathrm{x}$ & $\mathrm{x}$ & $\mathrm{x}(\mathrm{m})$ & $\mathrm{x}$ & \\
\hline Leucothoe incisa (Robertson, 1892) & 211 & 75 & ++++ & +++ & + & $14-135$ & $\mathrm{x}$ & $\mathrm{x}$ & $\mathrm{x}$ & $\mathrm{x}$ & $\mathrm{x}$ & $\mathrm{x}$ \\
\hline Leucothoe lilljeborgi Boeck, 1861 & 9 & 7 & & ++++ & & $38-91$ & $\mathrm{x}$ & $\mathrm{x}$ & $\mathrm{x}$ & $\mathrm{x}$ & $\mathrm{x}$ & $\mathrm{x}$ \\
\hline Leucothoe procera Bate, 1857 & 6 & 6 & +++ & ++++ & & $37-145$ & $\mathrm{x}$ & $\mathrm{x}$ & $\mathrm{x}$ & $\mathrm{x}$ & $\mathrm{x}$ & $\mathrm{x}$ \\
\hline Liljeborgia pallida (Bate, 1857) & 2 & 2 & ++++ & ++++ & & $82-131$ & $\mathrm{x}$ & $\mathrm{x}$ & $\mathrm{x}$ & $\mathrm{x}$ & $\mathrm{x}$ & $\mathrm{x}$ \\
\hline Lysianassa insperata (Lincoln, 1979) & 10 & 9 & ++++ & ++ & & $25-62$ & $\mathrm{x}$ & $\mathrm{x}$ & $\mathrm{x}$ & $\mathrm{x}$ & $\mathrm{x}$ & \\
\hline Lysianassa plumosa Boeck, 1871 & 2 & 1 & & ++++ & & 48 & $\mathrm{x}$ & $\mathrm{x}$ & $\mathrm{x}$ & $\mathrm{x}(\mathrm{m})$ & $\mathrm{x}$ & $\mathrm{x}$ \\
\hline Maera grossimana (Montagu, 1808) & 44 & 5 & ++++ & & & $37-179$ & $\mathrm{x}$ & $\mathrm{x}$ & $\mathrm{x}$ & $\mathrm{x}$ & $\mathrm{x}$ & $\mathrm{x}$ \\
\hline Maera inaequipes (Costa, 1857) & 1 & 1 & ++++ & & & 102 & $\mathrm{x}$ & $\mathrm{x}$ & $\mathrm{x}$ & $\mathrm{x}$ & $\mathrm{x}$ & $\mathrm{x}$ \\
\hline Maerella tenuimana (Bate, 1862) & 6 & 6 & ++++ & & & $14-179$ & $\mathrm{x}$ & $\mathrm{x}$ & $\mathrm{x}$ & $\mathrm{x}$ & $\mathrm{x}$ & \\
\hline Medicorophium minimum (Schiecke, 1978) & 7 & 6 & ++ & +++ & ++++ & $14-100$ & $\mathrm{x}$ & & & & $\mathrm{x}$ & \\
\hline Medicorophium runcicorne (Della Valle, 1893) & 1 & 1 & & ++++ & & 48 & $\mathrm{x}$ & & & $\mathrm{x}$ & $\mathrm{x}$ & $\mathrm{x}$ \\
\hline Megaluropus agilis Hoeck, 1889 & 65 & 27 & +++ & ++++ & + & $17-58$ & $\mathrm{x}$ & $\mathrm{x}$ & $\mathrm{x}$ & $\mathrm{x}$ & $\mathrm{x}$ & $\mathrm{x}$ \\
\hline Megamphopus brevidactylus Myers, 1976 & 3 & 2 & & ++++ & & $38-49$ & $\mathrm{x}$ & & & & $\mathrm{x}$ & \\
\hline Megamphopus cornutus Norman, 1869 & 165 & 49 & ++++ & ++ & & $14-100$ & $\mathrm{x}$ & $\mathrm{x}$ & $\mathrm{x}$ & $\mathrm{x}$ & $\mathrm{x}$ & $\mathrm{x}$ \\
\hline Melita cf. valesi Karaman, 1955 & 34 & 4 & ++++ & +++ & & $43-69$ & & & & $\mathrm{x}(\mathrm{m})$ & $\mathrm{x}$ & \\
\hline Melphidippella macra (Norman, 1869) & 1 & 1 & ++++ & & & 99 & $\mathrm{x}$ & $\mathrm{x}$ & $\mathrm{x}$ & $\mathrm{x}(\mathrm{m})$ & $\mathrm{x}$ & $\mathrm{x}$ \\
\hline Metaphoxus fultoni (Scott, 1890) & 54 & 18 & ++++ & + & & $31-99$ & $\mathrm{x}$ & $\mathrm{x}$ & $\mathrm{x}$ & $\mathrm{x}(\mathrm{m})$ & $\mathrm{x}$ & $\mathrm{x}$ \\
\hline Metaphoxus pectinatus (Walker, 1896) & 1 & 1 & ++++ & & & 111 & $\mathrm{x}$ & $\mathrm{x}$ & $\mathrm{x}$ & $\mathrm{x}$ & $\mathrm{x}$ & $\mathrm{x}$ \\
\hline Metopella sp. Stebbing, 1906 & 58 & 14 & ++++ & + & & $44-85$ & & $\mathrm{x}$ & & & & \\
\hline Microdeutopus armatus Chevreux, 1886 & 41 & 14 & ++++ & ++ & + & $29-87$ & $\mathrm{x}$ & $\mathrm{x}$ & $\mathrm{x}$ & $\mathrm{x}$ & $\mathrm{x}$ & \\
\hline Microdeutopus chelifer (Bate, 1862) & 6 & 4 & ++++ & & & $57-102$ & $\mathrm{x}$ & $\mathrm{x}$ & $\mathrm{x}$ & $\mathrm{x}$ & $\mathrm{x}$ & $\mathrm{x}$ \\
\hline Microdeutopus versiculatus (Bate, 1856) & 4 & 1 & & ++++ & & 38 & $\mathrm{x}$ & $\mathrm{x}$ & $\mathrm{x}$ & $\mathrm{x}$ & $\mathrm{x}$ & $\mathrm{x}$ \\
\hline Microprotopus longimanus Chevreux, 1887 & 1 & 1 & ++++ & & & 55 & $\mathrm{x}$ & $\mathrm{x}$ & $\mathrm{x}$ & $\mathrm{x}(\mathrm{m})$ & $\mathrm{x}$ & \\
\hline Monocorophium acherusicum (Costa, 1853) & 3 & 3 & +++ & +++ & +++ & $50-72$ & $\mathrm{x}$ & $\mathrm{x}$ & $\mathrm{x}$ & $\mathrm{x}$ & $\mathrm{x}$ & $\mathrm{x}$ \\
\hline Monoculodes carinatus (Bate, 1857) & 40 & 26 & ++++ & ++ & & $20-124$ & $\mathrm{x}$ & $\mathrm{x}$ & $\mathrm{x}$ & $\mathrm{x}$ & $\mathrm{x}$ & \\
\hline Normanion sarsi Stebbing, 1906 & 3 & 1 & ++++ & & & 99 & $\mathrm{x}$ & $\mathrm{x}$ & & & & \\
\hline Nototropis falcatus (Metzger, 1871) & 35 & 19 & ++++ & +++ & & $21-42$ & $\mathrm{x}$ & $\mathrm{x}$ & $\mathrm{x}$ & $\mathrm{x}$ & $\mathrm{x}$ & $\mathrm{x}$ \\
\hline $\begin{array}{l}\text { Nototropis swammerdamei (Milne-Edwards, } \\
\text { 1830) }\end{array}$ & 4 & 4 & ++++ & ++++ & & $23-52$ & $\mathrm{x}$ & $\mathrm{x}$ & $\mathrm{x}$ & $x$ & $\mathrm{x}$ & $\mathrm{x}$ \\
\hline Oedicerotidae n.i. Lilljeborg, 1865 & 2 & 2 & ++++ & & & $74-99$ & - & - & - & - & - & - \\
\hline Orchomene massiliensis Ledoyer, 1977 & 1 & 1 & & ++++ & & 38 & $\mathrm{x}$ & & $\mathrm{x}(\mathrm{m})$ & & $\mathrm{x}$ & \\
\hline Orchomene similis (Chevreux, 1912) & 48 & 7 & ++++ & & & $41-71$ & & $\mathrm{x}$ & $\mathrm{x}$ & & $\mathrm{x}$ & \\
\hline Othomaera othonis (Milne-Edwards, 1830) & 422 & 53 & ++++ & ++ & + & $14-179$ & $\mathrm{x}$ & $\mathrm{x}$ & $\mathrm{x}$ & $\mathrm{x}$ & $\mathrm{x}$ & $\mathrm{x}$ \\
\hline Pariambus typicus (Krøyer, 1884) & 179 & 26 & +++ & ++++ & & 21-101 & $\mathrm{x}$ & $\mathrm{x}$ & $\mathrm{x}$ & $\mathrm{x}$ & $\mathrm{x}$ & \\
\hline Peltocoxa brevirostris (Scott \& Scott, 1893) & 1 & 1 & ++++ & & & 99 & $\mathrm{x}$ & $\mathrm{x}$ & $\mathrm{x}(\mathrm{a})$ & $\mathrm{x}(\mathrm{a})$ & & \\
\hline $\begin{array}{l}\text { Perioculodes longimanus (Bate \& Westwood, } \\
\text { 1868) }\end{array}$ & 88 & 49 & +++ & ++++ & + & 23-135 & $\mathrm{x}$ & $\mathrm{x}$ & $\mathrm{x}$ & $\mathrm{x}$ & $\mathrm{x}$ & $\mathrm{x}$ \\
\hline Perrierella audouiniana (Bate, 1857) & 4 & 2 & & ++++ & & $47-48$ & $\mathrm{x}$ & $\mathrm{x}$ & $\mathrm{x}$ & $\mathrm{x}$ & $\mathrm{x}$ & $\mathrm{x}$ \\
\hline Photis longicaudata (Bate \& Westwood, 1862) & 20 & 11 & ++ & ++++ & ++ & $38-190$ & $\mathrm{x}$ & $\mathrm{x}$ & $\mathrm{x}$ & $\mathrm{x}$ & $\mathrm{x}$ & $\mathrm{x}$ \\
\hline Photis longipes (Della Valle, 1893) & 11 & 5 & ++++ & & ++ & $14-98$ & $\mathrm{x}$ & & $\mathrm{x}(\mathrm{m})$ & $\mathrm{x}$ & $\mathrm{x}$ & $\mathrm{x}$ \\
\hline Phtisica marina Slabber, 1769 & 27 & 18 & ++ & ++++ & ++ & $25-190$ & $\mathrm{x}$ & $\mathrm{x}$ & $\mathrm{x}$ & $\mathrm{x}$ & $\mathrm{x}$ & $\mathrm{x}$ \\
\hline $\begin{array}{l}\text { Pontocrates altamarinus (Bate \& Westwood, } \\
\text { 1862) }\end{array}$ & 26 & 9 & +++ & ++++ & & $15-44$ & $\mathrm{x}$ & $\mathrm{x}$ & $\mathrm{x}$ & $\mathrm{x}$ & $\mathrm{x}$ & $\mathrm{x}$ \\
\hline Pontocrates arenarius (Bate, 1858) & 51 & 25 & ++++ & +++ & & $25-100$ & $\mathrm{x}$ & $\mathrm{x}$ & $\mathrm{x}$ & $\mathrm{x}$ & $\mathrm{x}$ & $\mathrm{x}$ \\
\hline Psammogammarus caecus Karaman, 1955 & 157 & 37 & ++++ & + & ++ & $33-137$ & $\mathrm{x}$ & & $\mathrm{x}(\mathrm{m})$ & & $\mathrm{x}$ & \\
\hline Pseudolirius kroyeri (Haller, 1897) & 1 & 1 & ++++ & & & 57 & & $\mathrm{x}$ & $\mathrm{x}$ & $\mathrm{x}(\mathrm{m})$ & $\mathrm{x}$ & \\
\hline Pseudoprotella phasma Montagu, 1804 & 1 & 1 & ++++ & & & 36 & $\mathrm{x}$ & $\mathrm{x}$ & $\mathrm{x}$ & $\mathrm{x}$ & $\mathrm{x}$ & $\mathrm{x}$ \\
\hline $\begin{array}{l}\text { Siphonoecetes (Centraloecetes) striatus Myers \& } \\
\quad \text { McGrath, } 1979\end{array}$ & 5 & 4 & +++ & ++++ & & $31-100$ & $\mathrm{x}$ & $\mathrm{x}$ & $\mathrm{x}$ & $\mathrm{x}$ & $\mathrm{x}$ & \\
\hline Socarnes erythrophthalmus Robertson, 1892 & 536 & 36 & ++++ & +++ & + & $20-128$ & $\mathrm{x}$ & $\mathrm{x}$ & $\mathrm{x}$ & $\mathrm{x}$ & $\mathrm{x}$ & $\mathrm{x}$ \\
\hline Stenothoe marina (Bate, 1856) & 35 & 11 & ++++ & +++ & & $24-94$ & $\mathrm{x}$ & $\mathrm{x}$ & $\mathrm{x}$ & $\mathrm{x}$ & $\mathrm{x}$ & $\mathrm{x}$ \\
\hline Stenothoe valida Dana, 1852 & 2 & 1 & ++++ & & & 33 & $\mathrm{x}$ & $\mathrm{x}$ & $\mathrm{x}$ & & $\mathrm{x}$ & $\mathrm{x}$ \\
\hline Synchelidium haplocheles (Grube, 1864) & 1 & 1 & & ++++ & & 91 & $\mathrm{x}$ & $\mathrm{x}$ & $\mathrm{x}$ & $\mathrm{x}$ & $\mathrm{x}$ & $\mathrm{x}$ \\
\hline Synchelidium maculatum Stebbing, 1906 & 10 & 10 & ++ & ++++ & & $21-122$ & $\mathrm{x}$ & $\mathrm{x}$ & $\mathrm{x}$ & $\mathrm{x}$ & $\mathrm{x}$ & $\mathrm{x}$ \\
\hline Syrrhoites pusilla Enequist, 1949 & 3 & 2 & ++++ & ++++ & & $50-133$ & $\mathrm{x}$ & $\mathrm{x}$ & $\mathrm{x}$ & $\mathrm{x}(\mathrm{m})$ & $\mathrm{x}$ & \\
\hline
\end{tabular}


Table 4 (continued)

\begin{tabular}{|c|c|c|c|c|c|c|c|c|c|c|c|c|}
\hline \multirow[t]{2}{*}{ Species } & \multicolumn{6}{|c|}{ This study } & \multicolumn{6}{|l|}{ Literature } \\
\hline & A & $\mathrm{F}$ & CS & FS & M & $\begin{array}{l}\text { Depth } \\
\text { range } \\
\text { (meters) }\end{array}$ & Portugal & Britain & France & Spain & Mediterranean & $\begin{array}{l}\text { West Africa } \\
\text { and } \\
\text { Macaronesia }\end{array}$ \\
\hline Tmetonyx similis (Sars, 1891) & 1 & 1 & ++++ & & & 103 & $\mathrm{x}$ & $\mathrm{x}$ & $\mathrm{x}$ & $\mathrm{x}(\mathrm{m})$ & $\mathrm{x}$ & \\
\hline Tryphosa nana (Krøyer, 1846) & 2 & 2 & ++++ & ++++ & & $58-124$ & $\mathrm{x}$ & $\mathrm{x}$ & $\mathrm{x}$ & $\mathrm{x}$ & $\mathrm{x}$ & $\mathrm{x}$ \\
\hline Tryphosella sarsi Bonnier, 1893 & 36 & 6 & ++++ & & & $52-76$ & $\mathrm{x}$ & $\mathrm{x}$ & $\mathrm{x}$ & & $\mathrm{x}$ & \\
\hline Tryphosites longipes (Bate \& Westwood, 1861) & 7 & 3 & +++ & ++++ & & $23-57$ & $\mathrm{x}$ & $\mathrm{x}$ & $\mathrm{x}$ & $\mathrm{x}$ & $\mathrm{x}$ & $\mathrm{x}$ \\
\hline Unciola crenatipalma (Bate, 1862) & 9 & 5 & ++ & ++++ & & $62-128$ & $\mathrm{x}$ & $\mathrm{x}$ & $\mathrm{x}$ & $\mathrm{x}$ & $\mathrm{x}$ & \\
\hline Urothoe brevicornis Bate, 1862 & 16 & 2 & & ++++ & & $25-40$ & $\mathrm{x}$ & $\mathrm{x}$ & $\mathrm{x}(\mathrm{a})$ & $\mathrm{x}$ & & \\
\hline Urothoe elegans (Bate, 1857) & 23 & 12 & & ++++ & & $20-144$ & $\mathrm{x}$ & $\mathrm{x}$ & $\mathrm{x}$ & $\mathrm{x}$ & $\mathrm{x}$ & $\mathrm{x}$ \\
\hline Urothoe grimaldii Chevreux, 1895 & 36 & 16 & +++ & ++++ & & $33-100$ & $\mathrm{x}$ & & $\mathrm{x}$ & $\mathrm{x}$ & $\mathrm{x}$ & $\mathrm{x}$ \\
\hline Urothoe marina (Bate, 1857) & 24 & 8 & ++++ & & & $25-140$ & $\mathrm{x}$ & $\mathrm{x}$ & $\mathrm{x}$ & $\mathrm{x}$ & $\mathrm{x}$ & $\mathrm{x}$ \\
\hline Urothoe poseidonis Reibish, 1905 & 6 & 5 & ++ & ++++ & & $21-58$ & $\mathrm{x}$ & $\mathrm{x}$ & $\mathrm{x}$ & $\mathrm{x}$ & $\mathrm{x}$ & \\
\hline Urothoe pulchella (Costa, 1853) & 237 & 44 & ++ & ++++ & & $17-101$ & $\mathrm{x}$ & $\mathrm{x}$ & $\mathrm{x}$ & $\mathrm{x}$ & $\mathrm{x}$ & $\mathrm{x}$ \\
\hline Westwoodilla caecula (Bate, 1857) & 16 & 14 & + & ++++ & +++ & $48-147$ & $\mathrm{x}$ & $\mathrm{x}$ & $\mathrm{x}$ & $\mathrm{x}$ & $\mathrm{x}$ & $\mathrm{x}$ \\
\hline \multicolumn{13}{|l|}{ Cumacea } \\
\hline Bodotria arenosa Goodsir, 1843 & 1 & 1 & ++++ & & & 38 & $\mathrm{x}$ & $\mathrm{x}$ & $\mathrm{x}$ & $\mathrm{x}$ & $\mathrm{x}$ & \\
\hline Bodotria scorpioides (Montagu, 1804) & 137 & 28 & +++ & ++++ & + & 14-195 & $\mathrm{x}$ & $\mathrm{x}$ & $\mathrm{x}$ & $\mathrm{x}$ & $\mathrm{x}$ & \\
\hline Brachydiastylis resima (Krøyer, 1846) & 2 & 2 & & ++++ & & $134-139$ & $\mathrm{x}$ & $\mathrm{x}$ & & & & \\
\hline Campylaspis glabra Sars, 1878 & 100 & 16 & ++++ & & & $33-99$ & $\mathrm{x}$ & $\mathrm{x}$ & $\mathrm{x}$ & $\mathrm{x}$ & $\mathrm{x}$ & $\mathrm{x}$ \\
\hline Diastylis bradyi Norman, 1879 & 180 & 49 & ++ & ++++ & ++ & $17-190$ & $\mathrm{x}$ & $\mathrm{x}$ & $\mathrm{x}$ & $\mathrm{x}$ & $\mathrm{x}$ & \\
\hline Diastylis rugosa Sars, 1865 & 2 & 1 & ++++ & & & 16 & $\mathrm{x}$ & $\mathrm{x}$ & $\mathrm{x}$ & $\mathrm{x}$ & $\mathrm{x}$ & \\
\hline Diastyloides serratus (Sars G.O., 1865) & 1 & 1 & & & ++++ & 94 & $\mathrm{x}$ & $\mathrm{x}$ & $\mathrm{x}$ & $\mathrm{x}$ & $\mathrm{x}$ & \\
\hline Eocuma dimorphum Fage, 1928 & 3 & 2 & & ++++ & & $45-49$ & $\mathrm{x}$ & & $\mathrm{x}(\mathrm{a})$ & $\mathrm{x}(\mathrm{a})$ & & $\mathrm{x}$ \\
\hline Eocuma dolffusii Calman, 1907 & 2 & 2 & & ++++ & & $17-49$ & $\mathrm{x}$ & $\mathrm{x}$ & $\mathrm{x}$ & $\mathrm{x}$ & $\mathrm{x}$ & $\mathrm{x}$ \\
\hline Iphinoe serrata Norman, 1867 & 25 & 19 & ++ & ++++ & ++ & $14-190$ & $\mathrm{x}$ & $\mathrm{x}$ & $\mathrm{x}$ & $\mathrm{x}$ & $\mathrm{x}$ & $\mathrm{x}$ \\
\hline Iphinoe tenella Sars, 1878 & 3 & 2 & ++++ & ++++ & & $25-47$ & $\mathrm{x}$ & $\mathrm{x}$ & $\mathrm{x}$ & $\mathrm{x}$ & $\mathrm{x}$ & $\mathrm{x}$ \\
\hline Iphinoe trispinosa (Goodsir, 1843) & 84 & 29 & ++ & ++++ & ++ & $21-145$ & $\mathrm{x}$ & $\mathrm{x}$ & $\mathrm{x}$ & $\mathrm{x}$ & $\mathrm{x}$ & $\mathrm{x}$ \\
\hline $\begin{array}{l}\text { Pseudocuma (Pseudocuma) longicorne (Bate, } \\
\text { 1858) }\end{array}$ & 1 & 1 & & ++++ & & 93 & $\mathrm{x}$ & $\mathrm{x}$ & $\mathrm{x}$ & $\mathrm{x}$ & $\mathrm{x}$ & $\mathrm{x}$ \\
\hline Pseudocuma simile G.O. Sars, 1900 & 2 & 1 & ++++ & & & 80 & $\mathrm{x}$ & $\mathrm{x}$ & $\mathrm{x}$ & $\mathrm{x}$ & $\mathrm{x}$ & \\
\hline Vaunthompsonia cristata Bate, 1858 & 2 & 1 & & & ++++ & 73 & $\mathrm{x}$ & $\mathrm{x}$ & $\mathrm{x}$ & $\mathrm{x}$ & $\mathrm{x}$ & $\mathrm{x}$ \\
\hline \multicolumn{13}{|l|}{ Decapoda } \\
\hline Alpheus glaber (Olivi, 1792) & 20 & 16 & ++ & +++ & +++ & $46-148$ & $\mathrm{x}$ & $\mathrm{x}$ & $\mathrm{x}$ & $\mathrm{x}$ & $\mathrm{x}$ & $\mathrm{x}$ \\
\hline Anapagurus hyndmanni (Bell, 1846) & 37 & 18 & ++++ & +++ & + & 29-94 & $\mathrm{x}$ & $\mathrm{x}$ & $\mathrm{x}$ & $\mathrm{x}$ & $\mathrm{x}$ & $\mathrm{x}$ \\
\hline Anapagurus laevis (Bell, 1846) & 46 & 34 & +++ & +++ & + & $29-179$ & $\mathrm{x}$ & $\mathrm{x}$ & $\mathrm{x}$ & $\mathrm{x}$ & $\mathrm{x}$ & $\mathrm{x}$ \\
\hline Anapagurus pusillus Henderson, 1888 & 10 & 10 & +++ & ++++ & ++ & $25-120$ & $\mathrm{x}$ & & & $\mathrm{x}(\mathrm{a})$ & & $\mathrm{x}$ \\
\hline Atelecyclus rotundatus (Olivi, 1792) & 9 & 8 & ++++ & +++ & & $21-69$ & $\mathrm{x}$ & $\mathrm{x}$ & $\mathrm{x}$ & $\mathrm{x}$ & $\mathrm{x}$ & $\mathrm{x}$ \\
\hline $\begin{array}{l}\text { Athanas nitescens (Leach, } 1813 \text { [in Leach, } \\
\text { 1813-1814]) }\end{array}$ & 8 & 6 & & +++ & ++++ & $62-138$ & $\mathrm{x}$ & $\mathrm{x}$ & $\mathrm{x}$ & $\mathrm{x}$ & $\mathrm{x}$ & $\mathrm{x}$ \\
\hline Callianassa subterranea (Montagu, 1808) & 81 & 42 & + & ++++ & ++ & $46-145$ & $\mathrm{x}$ & $\mathrm{x}$ & $\mathrm{x}$ & $\mathrm{x}$ & $\mathrm{x}$ & $\mathrm{x}$ \\
\hline Corystes cassivelaunus (Pennant, 1777) & 2 & 2 & & ++++ & & $50-68$ & $\mathrm{x}$ & $\mathrm{x}$ & $\mathrm{x}$ & $\mathrm{x}$ & $\mathrm{x}$ & $\mathrm{x}$ \\
\hline Crangon crangon (Linnaeus, 1758) & 8 & 5 & ++++ & +++ & & $36-72$ & $\mathrm{x}$ & $\mathrm{x}$ & $\mathrm{x}$ & $\mathrm{x}$ & $\mathrm{x}$ & $\mathrm{x}$ \\
\hline Diogenes pugilator (Roux, 1829) & 46 & 17 & ++ & ++++ & & $17-124$ & $\mathrm{x}$ & $\mathrm{x}$ & $\mathrm{x}$ & $\mathrm{x}$ & $\mathrm{x}$ & $\mathrm{x}$ \\
\hline Ebalia granulosa $\mathrm{H}$. Milne Edwards, 1837 & 7 & 7 & ++++ & +++ & & $57-139$ & $\mathrm{x}$ & $\mathrm{x}$ & $\mathrm{x}$ & $\mathrm{x}$ & $\mathrm{x}$ & $\mathrm{x}$ \\
\hline Ebalia nux A. Milne-Edwards, 1883 & 17 & 13 & +++ & ++++ & + & $57-134$ & $\mathrm{x}$ & $\mathrm{x}$ & $\mathrm{x}$ & $\mathrm{x}$ & $\mathrm{x}$ & $\mathrm{x}$ \\
\hline Ebalia tuberosa (Pennant, 1777) & 2 & 2 & ++++ & & & $57-111$ & $\mathrm{x}$ & $\mathrm{x}$ & $\mathrm{x}$ & $\mathrm{x}$ & $\mathrm{x}$ & $\mathrm{x}$ \\
\hline Ebalia tumefacta (Montagu, 1808) & 11 & 8 & ++++ & +++ & & $29-131$ & $\mathrm{x}$ & $\mathrm{x}$ & $\mathrm{x}$ & $\mathrm{x}$ & $\mathrm{x}$ & $\mathrm{x}$ \\
\hline $\begin{array}{l}\text { Eualus cranchii (Leach, } 1817 \text { [in Leach, } \\
\text { 1815-1875]) }\end{array}$ & 3 & 2 & ++++ & ++++ & & $41-47$ & $\mathrm{x}$ & $\mathrm{x}$ & $\mathrm{x}$ & $\mathrm{x}$ & $\mathrm{x}$ & $\mathrm{x}$ \\
\hline Eurynome spinosa Hailstone, 1835 & 8 & 8 & & ++++ & ++ & $38-160$ & $\mathrm{x}$ & $\mathrm{x}$ & $\mathrm{x}$ & $\mathrm{x}$ & $\mathrm{x}$ & $\mathrm{x}$ \\
\hline Galathea intermedia Liljeborg, 1851 & 267 & 49 & ++++ & ++ & + & 111 & $\mathrm{x}$ & $\mathrm{x}$ & $\mathrm{x}$ & $\mathrm{x}$ & $\mathrm{x}$ & $\mathrm{x}$ \\
\hline Galathea strigosa (Linnaeus, 1761) & 1 & 1 & & ++++ & & 134 & $\mathrm{x}$ & $\mathrm{x}$ & $\mathrm{x}$ & $\mathrm{x}$ & $\mathrm{x}$ & $\mathrm{x}$ \\
\hline Goneplax rhomboides (Linnaeus, 1758) & 20 & 16 & & ++++ & +++ & $54-140$ & $\mathrm{x}$ & $\mathrm{x}$ & $\mathrm{x}$ & $\mathrm{x}$ & $\mathrm{x}$ & $\mathrm{x}$ \\
\hline Jaxea nocturna Nardo, 1847 & 3 & 3 & & ++++ & & $81-136$ & $\mathrm{x}$ & $\mathrm{x}$ & $\mathrm{x}$ & $\mathrm{x}$ & $\mathrm{x}$ & $\mathrm{x}$ \\
\hline Liocarcinus holsatus (Fabricius, 1798) & 2 & 2 & ++++ & & & $34-52$ & $\mathrm{x}$ & $\mathrm{x}$ & $\mathrm{x}$ & $\mathrm{x}$ & $\mathrm{x}$ & $\mathrm{x}$ \\
\hline Liocarcinus navigator (Herbst, 1794) & 5 & 3 & & +++ & ++++ & $31-159$ & $\mathrm{x}$ & $\mathrm{x}$ & $\mathrm{x}$ & $\mathrm{x}$ & $\mathrm{x}$ & $\mathrm{x}$ \\
\hline Liocarcinus pusillus (Leach, 1816) & 37 & 26 & ++++ & +++ & & 23-103 & $\mathrm{x}$ & $\mathrm{x}$ & $\mathrm{x}$ & $\mathrm{x}$ & $\mathrm{x}$ & $\mathrm{x}$ \\
\hline $\begin{array}{l}\text { Macropodia linaresi Forest \& Zariquiey Alvarez, } \\
1964\end{array}$ & 2 & 2 & ++++ & ++++ & & $34-46$ & $\mathrm{x}$ & $\mathrm{x}$ & $\mathrm{x}$ & $\mathrm{x}$ & $\mathrm{x}$ & $\mathrm{x}$ \\
\hline Michelopagurus atlanticus (Bouvier, 1922) & 1 & 1 & & ++++ & & 41 & & & & & & $\mathrm{x}$ \\
\hline Munida tenuimana Sars, 1872 & 1 & 1 & & ++++ & & 48 & $\mathrm{x}$ & $\mathrm{x}$ & $\mathrm{x}$ & $\mathrm{x}$ & $\mathrm{x}$ & $\mathrm{x}$ \\
\hline Necallianassa truncata (Giard \& Bonnier, 1890) & 204 & 48 & ++ & ++++ & + & $21-134$ & $\mathrm{x}$ & $\mathrm{x}$ & $\mathrm{x}$ & $\mathrm{x}$ & $\mathrm{x}$ & $\mathrm{x}$ \\
\hline Nepinnotheres pinnotheres (Linnaeus, 1758) & 1 & 1 & & & ++++ & 110 & $\mathrm{x}$ & $\mathrm{x}$ & $\mathrm{x}$ & $\mathrm{x}$ & $\mathrm{x}$ & $\mathrm{x}$ \\
\hline Pagurus chevreuxi (Bouvier, 1896) & 8 & 7 & +++ & ++++ & & $25-50$ & $\mathrm{x}$ & $\mathrm{x}$ & $\mathrm{x}$ & $\mathrm{x}$ & $\mathrm{x}$ & $\mathrm{x}$ \\
\hline Pagurus cuanensis Bell, 1846 & 2 & 2 & ++++ & ++++ & & $31-91$ & $\mathrm{x}$ & $\mathrm{x}$ & $\mathrm{x}$ & $\mathrm{x}$ & $\mathrm{x}$ & $\mathrm{x}$ \\
\hline Pagurus excavatus (Herbst, 1791) & 2 & 2 & ++++ & ++++ & & $82-90$ & $\mathrm{x}$ & & $\mathrm{x}$ & $\mathrm{x}$ & $\mathrm{x}$ & $\mathrm{x}$ \\
\hline Pandolina brevirostris (Rathke, 1843) & 7 & 7 & ++++ & ++ & & $44-140$ & $\mathrm{x}$ & $\mathrm{x}$ & $\mathrm{x}$ & $\mathrm{x}$ & $\mathrm{x}$ & $\mathrm{x}$ \\
\hline $\begin{array}{l}\text { Philocheras bispinosus bispinosus (Hailstone, } \\
\text { 1835a) }\end{array}$ & 55 & 28 & +++ & +++ & ++ & $24-118$ & $\mathrm{x}$ & $\mathrm{x}$ & $\mathrm{x}$ & $\mathrm{x}$ & $\mathrm{x}$ & $\mathrm{x}$ \\
\hline $\begin{array}{l}\text { Philocheras sculptus (Bell, } 1847 \text { [in Bell, } \\
\text { 1844-1853]) }\end{array}$ & 4 & 4 & ++++ & +++ & & $43-179$ & $\mathrm{x}$ & $\mathrm{x}$ & $\mathrm{x}$ & $\mathrm{x}$ & $\mathrm{x}$ & $\mathrm{x}$ \\
\hline Philocheras trispinosus (Hailstone in Hailstone \& & 8 & 6 & & ++++ & & $21-49$ & $\mathrm{x}$ & $\mathrm{x}$ & $\mathrm{x}$ & $\mathrm{x}$ & $\mathrm{x}$ & $\mathrm{x}$ \\
\hline
\end{tabular}


Table 4 (continued)

\begin{tabular}{|c|c|c|c|c|c|c|c|c|c|c|c|c|}
\hline \multirow[t]{2}{*}{ Species } & \multicolumn{6}{|c|}{ This study } & \multicolumn{6}{|l|}{ Literature } \\
\hline & A & $\mathrm{F}$ & CS & FS & M & $\begin{array}{l}\text { Depth } \\
\text { range } \\
\text { (meters) }\end{array}$ & Portugal & Britain & France & Spain & Mediterranean & $\begin{array}{l}\text { West Africa } \\
\text { and } \\
\text { Macaronesia }\end{array}$ \\
\hline \multicolumn{13}{|l|}{ Westwood, 1835) } \\
\hline Pisidia longicornis (Linnaeus, 1767) & 8 & 2 & ++++ & & & $37-46$ & $\mathrm{x}$ & $\mathrm{x}$ & $\mathrm{x}$ & $\mathrm{x}$ & $\mathrm{x}$ & $\mathrm{x}$ \\
\hline Polybius henslowii Leach, 1820 & 9 & 8 & ++++ & +++ & & $14-52$ & $\mathrm{x}$ & $\mathrm{x}$ & $\mathrm{x}$ & $\mathrm{x}$ & $\mathrm{x}$ & $\mathrm{x}$ \\
\hline Portumnus latipes (Pennant, 1777) & 3 & 2 & ++++ & & & $44-47$ & $\mathrm{x}$ & $\mathrm{x}$ & $\mathrm{x}$ & $\mathrm{x}$ & $\mathrm{x}$ & $\mathrm{x}$ \\
\hline Processa edulis crassipes Nouvel \& Holthuis, 1957 & 3 & 2 & ++++ & ++++ & & $25-31$ & $\mathrm{x}$ & $\mathrm{x}$ & $\mathrm{x}$ & $\mathrm{x}$ & $\mathrm{x}$ & $\mathrm{x}$ \\
\hline $\begin{array}{l}\text { Processa modica modica Williamson in } \\
\text { Williamson \& Rochanaburanon, } 1979\end{array}$ & 11 & 11 & ++++ & +++ & + & $25-134$ & $\mathrm{x}$ & $\mathrm{x}$ & $\mathrm{x}$ & $\mathrm{x}$ & $\mathrm{x}$ & $\mathrm{x}$ \\
\hline $\begin{array}{l}\text { Processa nouveli holthuisi Al-Adhub \& } \\
\quad \text { Williamson, } 1975\end{array}$ & 56 & 29 & ++++ & +++ & + & 25-179 & $\mathrm{x}$ & $\mathrm{x}$ & $\mathrm{x}$ & $\mathrm{x}$ & $\mathrm{x}$ & $\mathrm{x}$ \\
\hline Thia scutellata (Fabricius, 1793) & 3 & 3 & ++++ & & & $44-121$ & $\mathrm{x}$ & $\mathrm{x}$ & $\mathrm{x}$ & $\mathrm{x}$ & $\mathrm{x}$ & $\mathrm{x}$ \\
\hline Upogebia deltaura (Leach, 1815) & 12 & 7 & ++++ & +++ & ++ & $48-133$ & $\mathrm{x}$ & $\mathrm{x}$ & $\mathrm{x}$ & $\mathrm{x}$ & $\mathrm{x}$ & $\mathrm{x}$ \\
\hline Upogebia pusilla (Petagna, 1792) & 3 & 3 & & ++++ & & 49-139 & $\mathrm{x}$ & $\mathrm{x}$ & $\mathrm{x}$ & $\mathrm{x}$ & $\mathrm{x}$ & $\mathrm{x}$ \\
\hline Xantho pilipes A. Milne-Edwards, 1867 & 1 & 1 & ++++ & & & 25 & $\mathrm{x}$ & $\mathrm{x}$ & $\mathrm{x}$ & $\mathrm{x}$ & $\mathrm{x}$ & $\mathrm{x}$ \\
\hline \multicolumn{13}{|l|}{ Isopoda } \\
\hline Anthuridae n.i. Leach, 1814 & 20 & 4 & ++++ & & & $25-88$ & - & - & - & - & - & - \\
\hline Astacilla dilatata Sars, 1882 & 10 & 6 & ++++ & ++++ & & $26-131$ & & $\mathrm{x}$ & $\mathrm{x}$ & $\mathrm{x}$ & $\mathrm{x}$ & \\
\hline Astacilla sp. Cordiner, 1793 & 3 & 3 & ++++ & & & $33-69$ & $\mathrm{x}$ & $\mathrm{x}$ & $\mathrm{x}$ & $\mathrm{x}$ & $\mathrm{x}$ & \\
\hline Bopyridae n.i. Rafinesque, 1815 & 1 & 1 & & ++++ & & 128 & - & - & - & - & - & - \\
\hline Cirolana cranchii Leach, 1818 & 13 & 1 & & ++++ & & 38 & $\mathrm{x}$ & $\mathrm{x}$ & & $\mathrm{x}$ & $\mathrm{x}$ & $\mathrm{x}$ \\
\hline Conilera cylindracea (Montagu, 1804) & 83 & 13 & ++++ & ++ & & 14-99 & $\mathrm{x}$ & $\mathrm{x}$ & $\mathrm{x}$ & $\mathrm{x}$ & $\mathrm{x}$ & \\
\hline Cortezura sp. Schultz, 1977 & 15 & 9 & ++++ & ++ & & $26-111$ & & & & & & \\
\hline Cymodoce truncata Leach, 1814 & 83 & 23 & ++++ & + & & 100 & $\mathrm{x}$ & $\mathrm{x}$ & $\mathrm{x}$ & $\mathrm{x}$ & $\mathrm{x}$ & $\mathrm{x}$ \\
\hline Entoniscidade n.i. Kossmann, 1881 & 1 & 1 & & ++++ & & 78 & - & - & - & - & - & - \\
\hline Eurydice naylori Jones \& Pierpoint, 1997 & 117 & 39 & ++++ & + & & $37-142$ & $\mathrm{x}$ & & & $\mathrm{x}$ & $\mathrm{x}$ & \\
\hline Eurydice pulchra Leach, 1815 & 29 & 14 & ++++ & + & & 14-99 & $\mathrm{x}$ & $\mathrm{x}$ & $\mathrm{x}$ & $\mathrm{x}$ & $\mathrm{x}$ & $\mathrm{x}$ \\
\hline Eurydice spinigera Hansen, 1890 & 57 & 19 & ++++ & + & & 25-195 & $\mathrm{x}$ & $\mathrm{x}$ & $\mathrm{x}$ & $\mathrm{x}$ & $\mathrm{x}$ & $\mathrm{x}$ \\
\hline Gnathia oxyuraea (Lilljeborg, 1855) & 32 & 21 & +++ & ++++ & & $29-160$ & & $\mathrm{x}$ & $\mathrm{x}$ & $\mathrm{x}$ & $\mathrm{x}$ & \\
\hline Hyssuridae n.i. Wägele, 1981 & 1 & 1 & & ++++ & & 29 & - & - & - & - & - & - \\
\hline Ianiropsis breviremis (Sars, 1883) & 10 & 5 & ++++ & & & $33-52$ & $\mathrm{x}$ & $\mathrm{x}$ & & $\mathrm{x}$ & $\mathrm{x}$ & $\mathrm{x}$ \\
\hline Jaera sp. Leach, 1814 & 2 & 2 & ++++ & ++++ & & $97-99$ & $\mathrm{x}$ & $\mathrm{x}$ & $\mathrm{x}$ & $\mathrm{x}$ & $\mathrm{x}$ & $\mathrm{x}$ \\
\hline Janira maculosa Leach, 1814 & 3 & 2 & ++++ & & & $36-52$ & $\mathrm{x}$ & $\mathrm{x}$ & $\mathrm{x}$ & $\mathrm{x}$ & $\mathrm{x}$ & $\mathrm{x}$ \\
\hline Janiridae n.i. Sars, 1897 & 2 & 1 & ++++ & & & 99 & - & - & - & - & - & - \\
\hline Kupellonura sp. Barnard, 1925 & 13 & 6 & ++ & ++++ & & 29-99 & $\mathrm{x}$ & & & $\mathrm{x}(\mathrm{m})$ & $\mathrm{x}$ & \\
\hline Leptanthura sp. Sars, 1897 & 1 & 1 & ++++ & & & 99 & $\mathrm{x}$ & $\mathrm{x}$ & $\mathrm{x}$ & $\mathrm{x}$ & $\mathrm{x}$ & \\
\hline Microjaera anisopoda Bocquet \& Levi, 1955 & 108 & 18 & ++++ & + & + & $25-122$ & & $\mathrm{x}$ & & $\mathrm{x}$ & $\mathrm{x}$ & $\mathrm{x}$ \\
\hline Munna kroyeri Goodsir, 1842 & 1 & 1 & ++++ & & & 53 & $\mathrm{x}$ & $\mathrm{x}$ & $\mathrm{x}$ & $\mathrm{x}$ & $\mathrm{x}$ & \\
\hline Natatolana gallica (Hansen, 1905) & 9 & 7 & ++++ & ++ & & $15-133$ & $\mathrm{x}$ & $\mathrm{x}$ & $\mathrm{x}$ & $\mathrm{x}$ & $\mathrm{x}$ & $\mathrm{x}$ \\
\hline Natatolana sp. Bruce, 1981 & 15 & 12 & +++ & ++++ & & $26-160$ & $\mathrm{x}$ & $\mathrm{x}$ & $\mathrm{x}$ & $\mathrm{x}$ & $\mathrm{x}$ & $\mathrm{x}$ \\
\hline Rocinela dumerilii (Lucas, 1849) & 1 & 1 & & ++++ & & 48 & $\mathrm{x}$ & $\mathrm{x}$ & & $\mathrm{x}(\mathrm{m})$ & $\mathrm{x}$ & \\
\hline \multicolumn{13}{|l|}{ Mysida } \\
\hline $\begin{array}{l}\text { Acanthomysis longicornis (Milne-Edwards, } \\
\text { 1837) }\end{array}$ & 4 & 4 & +++ & ++++ & & $33-100$ & $\mathrm{x}$ & $\mathrm{x}$ & $\mathrm{x}$ & $\mathrm{x}$ & $\mathrm{x}$ & \\
\hline Anchialina agilis (Sars G.O., 1877) & 19 & 11 & ++++ & ++ & + & $16-133$ & $\mathrm{x}$ & $\mathrm{x}$ & $\mathrm{x}$ & $\mathrm{x}$ & $\mathrm{x}$ & $\mathrm{x}$ \\
\hline Erythrops elegans (Sars G.O., 1863) & 1 & 1 & ++++ & & & 101 & $\mathrm{x}$ & $\mathrm{x}$ & $\mathrm{x}$ & $\mathrm{x}$ & $\mathrm{x}$ & $\mathrm{x}$ \\
\hline Gastrosaccus sanctus (Van Beneden, 1861) & 114 & 5 & +++ & ++++ & & $17-69$ & $\mathrm{x}$ & $\mathrm{x}$ & $\mathrm{x}$ & $\mathrm{x}$ & $\mathrm{x}$ & $\mathrm{x}$ \\
\hline Gastrosaccus spinifer (Goës, 1864) & 922 & 24 & ++++ & ++ & & $15-111$ & $\mathrm{x}$ & $\mathrm{x}$ & $\mathrm{x}$ & $\mathrm{x}$ & $\mathrm{x}$ & $\mathrm{x}$ \\
\hline Haplostylus normani (Sars G.O., 1877) & 330 & 41 & ++++ & ++ & & $14-142$ & $\mathrm{x}$ & $\mathrm{x}$ & $\mathrm{x}$ & $\mathrm{x}$ & $\mathrm{x}$ & $\mathrm{x}$ \\
\hline Heteromysis norvegica G.O. Sars, 1882 & 2 & 1 & ++++ & & & 50 & $\mathrm{x}$ & $\mathrm{x}$ & $\mathrm{x}$ & $\mathrm{x}$ & $\mathrm{x}$ & \\
\hline Leptomysis gracilis (Sars G.O., 1864) & 4 & 4 & ++++ & +++ & +++ & $48-122$ & $\mathrm{x}$ & $\mathrm{x}$ & $\mathrm{x}$ & $\mathrm{x}$ & $\mathrm{x}$ & $\mathrm{x}$ \\
\hline Lophogaster typicus M. Sars, 1857 & 4 & 4 & & ++++ & & $103-139$ & $\mathrm{x}$ & $\mathrm{x}$ & $\mathrm{x}$ & $\mathrm{x}$ & $\mathrm{x}$ & $\mathrm{x}$ \\
\hline Mysides insignis (Sars G.O., 1864) & 1 & 1 & & ++++ & & 78 & $\mathrm{x}$ & $\mathrm{x}$ & $\mathrm{x}(\mathrm{a})$ & $\mathrm{x}(\mathrm{a})$ & & \\
\hline Schistomysis ornata (Sars G.O., 1864) & 8 & 5 & +++ & +++ & ++ & 23-103 & $\mathrm{x}$ & $\mathrm{x}$ & $x(a)$ & $\mathrm{x}(\mathrm{a})$ & & \\
\hline Schistomysis spiritus (Norman, 1860) & 2 & 2 & ++++ & ++++ & & $17-48$ & $\mathrm{x}$ & $\mathrm{x}$ & $\mathrm{x}(\mathrm{a})$ & $x(a)$ & & $\mathrm{x}$ \\
\hline \multicolumn{13}{|l|}{ Other taxa } \\
\hline Apseudes talpa (Montagu, 1808) & 99 & 18 & +++ & ++++ & ++ & $16-168$ & $\mathrm{x}$ & $\mathrm{x}$ & $\mathrm{x}$ & $\mathrm{x}$ & $\mathrm{x}$ & $\mathrm{x}$ \\
\hline Apseudopsis latreillii (Milne-Edwards, 1828) & 30 & 15 & & ++++ & & $37-140$ & $\mathrm{x}$ & $\mathrm{x}$ & $\mathrm{x}$ & $\mathrm{x}$ & $\mathrm{x}$ & $\mathrm{x}$ \\
\hline Meganyctiphanes norvegica (M. Sars, 1857) & 12 & 10 & ++ & ++++ & ++ & $35-190$ & $\mathrm{x}$ & $\mathrm{x}$ & & $\mathrm{x}$ & $\mathrm{x}$ & $\mathrm{x}$ \\
\hline $\begin{array}{l}\text { Nebalia troncosoi Moreira, Cacabelos \& } \\
\text { Dominguez, } 2003\end{array}$ & 12 & 4 & ++++ & +++ & +++ & 23-103 & & $\mathrm{x}$ & & $\mathrm{x}(\mathrm{a})$ & & \\
\hline Ostracoda n.i. Latreille, 1802 & 34 & 19 & ++++ & +++ & & $38-139$ & - & - & - & - & - & - \\
\hline $\begin{array}{l}\text { Sarsinebalia cristoboi Moreira, Gestoso, } \\
\text { Troncoso, } 2003\end{array}$ & 359 & 43 & ++++ & + & & $25-97$ & & $\mathrm{x}$ & & $\mathrm{x}(\mathrm{a})$ & & \\
\hline $\begin{array}{l}\text { Sarsinebalia urgorii Moreira, Gestoso, Troncoso, } \\
2003\end{array}$ & 1 & 1 & ++++ & & & 85 & & $\mathrm{x}$ & & $\mathrm{x}(\mathrm{a})$ & & \\
\hline Scalpellum scalpellum (Linnaeus, 1767) & 1 & 1 & & & ++++ & 94 & $\mathrm{x}$ & $\mathrm{x}$ & $\mathrm{x}$ & $\mathrm{x}$ & $\mathrm{x}$ & $\mathrm{x}$ \\
\hline Semibalanus balanoides (Linnaeus, 1767) & 2 & 2 & & ++++ & & $90-100$ & $\mathrm{x}$ & $\mathrm{x}$ & $\mathrm{x}$ & $\mathrm{x}$ & $\mathrm{x}$ & $\mathrm{x}$ \\
\hline Tanaidacea n.i. Dana, 1849 & 66 & 19 & ++++ & ++ & + & $25-100$ & - & - & - & - & - & - \\
\hline
\end{tabular}


Lourido et al. (2008) found a similar assemblage with Bathyporeia elegans, exclusive and A. brevicornis, constant, in the fine sands of Ría de Aldán. This assemblage is also accompanied by other noncrustacean species linked to the macrofauna nearshore hydrodynamic exposed fine sands assemblage (Martins et al., 2013a), the polychaete nearshore shelf fine sands group (Martins et al., 2013b) and the molluscan Angulus fabula community (Martins et al., 2014).

The affinity group $\mathrm{C} 2$ corresponds to the heterogeneous fine sands deep assemblage with $A$. pectenata and $B$. scorpioides, characterized by low richness and abundance. This assemblage shows no clear resemblance with other known marine biocoenoses. Zenetos et al. (1997) also classified a complex assemblage from a similar heterogeneous circalitoral environment in the Mediterranean which also included the bivalve Timoclea ovata, characterized by a doubtful biocoenotic identity, and other species tolerant to mixed sediments. This assemblage corresponds to the macrofauna southwestern deep shelf assemblage described by Martins et al. (2013a), to the polychaete southwestern deep shelf assemblage (Martins et al., 2013b) or the molluscan Saccella commutata community (Martins et al., 2014).

Finally, the deep muddy sands assemblage (group C3) showed high species richness and shared some species with the Northern Europe Abra alba community described by Glémarec (1973) and Thorson (1957). This assemblage seems to represent a mix of two important Mediterranean deep communities described by Pérès and Picard (1964), the terrigeneous coastal muds and the bathyal muds biocoenoses, characterized by decapods such as Alpheus glaber, Anapagurus laevis, C. subterranea and Goneplax rhomboides. Zavodnik et al. (2005) described a similar assemblage in the North Adriatic Sea, colonized by the silt-tolerant axiid $C$. subterranea and associated to a mixed faunal composition of species characteristic of coastal terrigeneous ooze and bathyal silt biocoenoses. This community is found associated to the macrofauna mud community (Martins et al., 2013a), to the polychaete mud assemblage (Martins et al., 2013b), and the Tellina compressaAbra alba community (Martins et al., 2014), described for the Portuguese coast.

\subsection{Environmental-biological relationships}

Benthic studies have confirmed a relationship between the distribution of soft bottom benthic macrofauna and abiotic factors, such as sediment grain-size, oxygen availability, organic matter, depth, and hydrodynamics (among others, Coll et al., 2010; Dauvin, 2015; Dolbeth et al., 2007; Hily et al., 2008; Levin and Gage, 1998; Lourido et al., 2008). Sediment grain-size is probably the major determinant of the macrobenthic communities' composition (Basford et al., 1990). The Portuguese shelf crustacean assemblages confirmed this and corresponded well to a range of sediment types: coarse sediments (groups A and B1), heterogeneous medium or fine sediments (B2 and $\mathrm{C} 2$ ), fine sands (C1), and muddy sands (C3). Other studies have also suggested this primary response for sediment grain-size, namely in the continental shelves of Crete (Karakassis and Eleftheriou, 1997), North Bay of Biscay (Hily et al., 2008), Ría de Aldán (Lourido et al., 2008), Bay of Banyuls-sur-mer (northwestern Mediterranean Sea; Grémare et al., 1998), Bay of Veys (English Channel; Dauvin et al., 2004), to mention a few. The distribution of the sediments and associated organic content along the Portuguese shelf reflects their origin and the intensity of the hydrodynamics on the coast (Martins et al., 2012). The coarser sediments in the northwestern exposed shelf provide several interstitial microhabitats for small-sized organisms, good oxygen penetration and topographic relieves suitable for several crustacean species. As a result, the interstitial space between the grains of sediment and the surface relief can support a high abundance and diversity of crustacean species (Rees et al., 1999). In this study, the crustacea abundance was six to seven times higher in gravel or coarser sand than in mud, and the alpha diversity was 3 times higher in gravel than in mud. The impoverished finer sediments are prevalent in the sheltered southern coast and off the major rivers which contribute to an input of terrigenous particles and urban and industrial residuals (Martins et al., 2012). The decrease of abundance and diversity in shelf mud sediments had already been reported and potencially related to historic contamination originated inland (Martins et al., 2012; Quintino et al., 2001; Silva et al., 2004). Moreover, in areas where upwelling is intense, oxygen can drop to minimal levels, in less permeable fine sediments, and also influence the macrofauna distribution, particularly of molluscs and crustaceans (Levin and Gage, 1998; Weston, 1988).

Depth (or associated descriptors) is also related to the distribution of the benthic macrofauna in the Portuguese shelf (Cunha et al., 1997; Dolbeth et al., 2007; Freitas et al., 2011; Martins et al., 2013a, 2013b, 2014), as well as in other continental shelves (Basford et al., 1990; Moulaert et al., 2007). This study highlighted the decrease of crustacean alpha diversity and abundance with increasing depth, as already denoted in other benthic groups in the region (Cunha et al., 1997; Martins et al., 2013a, 2013b, 2014) or among other Mediterranean and Western Atlantic benthic communities (Coll et al., 2010; Bergen et al., 2001). Reduced food availability and nutritional quality with increasing depth can contribute to such abundance and diversity decline (Karakassis and Eleftheriou, 1997), among other factors. Regarding some low abundance and diversity observed in the near shore shelf community in this study, this should be mainly due to its exposure to a high energy environment with possibly strong bottom currents and not to depth itself, as was also indicated by Dolbeth et al. (2007); Martins et al. (2013a, 2013b, 2014); Reis et al. (1982) or Rodrigues and Quintino (1987). Overall, the literature shows different relationships across areas between depth and both macrofaunal diversity and abundance (Brooks et al., 2006 and references therein). While some of these differences can be explained by physico-chemical factors, one needs to take into account possible biological interactions that can influence diversity and how they vary from one region to another (Gooday et al., 2010).

Latitude was also related to the distribution of the crustacean assemblages along the Portuguese shelf with diversity increasing with increasing latitude (except for northernmost latitudes), a pattern shown along the North Atlantic for nematodes (Lambshead et al., 2000) and polychaetes (Dauvin et al., 1994) or in benthic communities of Italian transitional waters (Munari and Mistri, 2008). An opposite trend to that shown in many studies where a benthic diversity decline with increasing latitude is observed, diminishing towards high latitudes in both southern and northern hemispheres (e.g. Roy et al., 1998, 2004; Witman et al., 2004). In this study, the pattern could be related to an extension of species' range edges, particularly of southern species, due to water temperature increase as a result of climate warming (Bates et al., 2014). The diversity increases in the range edges as cold and warm species coexist. On the other end, in the northernmost latitudes, one would expect a diversity decrease as cold species' range edges contract and conditions are still harsh for warmer species to shift northerly (Bates et al., 2014). Hence, the co-occurrence in the Portuguese continental shelf of species from different biogeographic provinces can be explained by the latitudinal gradient, the species climate-mediated range shifts and the geographical context: Temperate cold and/or ArcticBoreal (e.g. Apherusa cirrus, Argissa hamatipes, Brachydiastylis resima), Lusitanean (e.g. Ampelisca remora, Sarsinebalia cristoboi, Urothoe brevicornis), Mediterranean (Caprella lilliput, Idunella excavata, Medicorophium minimum), Macaronesian and/or West African (e.g. Ampelisca verga, Anapagurus pusillus, Michelopagurus atlanticus). A high diversity and the co-occurrence of northern and southern species show that the Portuguese coast is a transitional zone with high ecological and biogeographic importance (Marques and Bellan-Santini, 1991; Martins et al., 2013a, 2013b, 2014). The prevalence of a complex current system along the Portuguese shelf, where subtropical warm waters from Africa and the Mediterranean Sea and Northern cold waters meet (Fiúza, 1983) is essential to sustain such diversity. Geological modifications on the coast morphology, such as the presence of canyons or other morphological barriers can also influence the latitudinal 
distribution of species (Cunha et al., 2011; Spalding et al., 2007). Along the western Portuguese shelf major submarine canyons (Nazaré, Lisboa and S. Vicente) may slow down the progression of colder species further south and southern species further north by acting as barriers and limiting the spatial distribution of those species (Martins et al., 2013a, 2013b, 2014).

In conclusion, the Portuguese continental shelf reunites favorable environmental conditions to support diverse benthic crustacean communities from Atlantic, Mediterranean, Macaronesian and West African origins acting as an important transition zone between regions and enhancing European species richness.

\section{Acknowledgements}

Leandro Sampaio benefited from a Post-doc grant (SFRH/BPD/ 72997/2010), Renato Mamede benefited from a Ph.D. grant (SFRH/BD/ 74312/2010) and Roberto Martins benefited from a Ph.D. grant (SFRH/ BD/44231/2008), all awarded by the Portuguese Foundation for Science and Technology (FCT - Fundação para a Ciência e Tecnologia). This investigation was supported by the research projects "ACOSHELF" (POCI/MAR/56441/2004-PPCDT/MAR/56441/2004), “Monitorização Ambiental do Emissário Submarino e da ETAR da Guia do Sistema de Saneamento da Costa do Estoril", funded by SANEST, S.A. and "MeshAtlantic" (with the support of the European Union ERDFAtlantic Area Program 2009-1/110). Thanks are due, for the financial support to CESAM (UID/AMB/50017/2013), to FCT/MEC through national funds, and the co-funding by the FEDER, within the PT2020 Partnership Agreement and Compete 2020.

\section{References}

Allen, J.A., 1967. Crustacea: Euphausiacea and Decapoda with an Illustrated Key to British Species. The Fauna of the Clyde Sea. Scottish Marine Biological Association, Millport (116 pp).

Almeida, C.P., 2008. Distribuição e padrões de utilização das conchas de caranguejos eremitas (Anomura) da costa do Algarve. Dissertação de Mestrado. Universidade do Algarve, Portugal (65 pp). (Available online at) http://hdl.handle.net/10400.1/352.

Appeltans, W., Ahyong, S.T., Anderson, G., Angel, M.V., Artois, T., Bailly, N., Bamber, R., Barber, A., Bartsch, I., Berta, A., Błazewicz-Paszkowycz, M., Bock, P., Boxshall, G., Boyko, C.B., Brandão, S.N., Bray, R.A., Bruce, N.L., Cairns, S.D., Chan, T.Y., Cheng, L., Collins, A.G., Cribb, T., Curini-Galletti, M., Dahdouh-Guebas, F., Davie, P.J.F., Dawson, M.N., de Clerck, O., Decock, W., de Grave, S., de Voogd, N.J., Domning, D.P., Emig, C.C., Erse'us, C., Eschmeyer, W., Fauchald, K., Fautin, D.G., Feist, S.W., Fransen, C.H.J.M., Furuya, H., Garcia-Alvarez, O., Gerken, S., Gibson, D., Gittenberger, A., Gofas, S., Gómez-Daglio, L., Gordon, D.P., Guiry, M.D., Hernandez, F., Hoeksema, B.W., Hopcroft, R.R., Jaume, D., Kirk, P., Koedam, N., Koenemann, S., Kolb, J.B., Kristensen, R.M., Kroh, A., Lambert, G., Lazarus, D.B., Lemaitre, R., Longshaw, M., Lowry, J., Macpherson, E., Madin, L.P., Mah, C., Mapstone, G., McLaughlin, P.A., Mees, J., Meland, K., Messing, C.G., Mills, C.E., Molodtsova, T.N., Mooi, R., Neuhaus, B., Ng P.K.L., Nielsen, C., Norenburg, J., Opresko, D.M., Osawa, M., Paulay, G., Perrin, W., Pilger, J.F., Poore, G.C.B., Pugh, P., Read, G.B., Reimer, J.D., Rius, M., Rocha, R.M., SaizSalinas, J.I., Scarabino, V., Schierwater, B., Schmidt-Rhaesa, A., Schnabel, K.E., Schotte, M., Schuchert, P., Schwabe, E., Segers, H., Self-Sullivan, C., Shenkar, N., Siegel, V., Sterrer, W., Stöhr, S., Swalla, B., Tasker, M.L., Thuesen, E.V., Timm, T., Todaro, M.A., Turon, X., Tyler, S., Uetz, P., van der Land, J., Vanhoorne, B., van Ofwegen, L.P., van Soest, R.W.M., Vanaverbeke, J., Walker-Smith, G., Walter, T.C. Warren, A., Williams, G.C., Wilson, S.P., Costello, M.J., 2012. The magnitude of global marine species diversity. Curr. Biol. 22, 2189-2202.

Araújo, R., Bárbara, I., Sousa-Pinto, L., Quintino, V., 2005. Spatial variability of intertidal rocky assemblages in the northwest coast of Portugal. Estuar. Coast. Shelf Sci. 64, 658-670.

Aslan-Cihangir, H., Pancucci-Papadopoulou, M.A., 2011. Spatial and temporal variation of soft-bottom peracarid (crustacea: peracarida) infauna in the Canakkale Strait (Turkey). Mediterr. Mar. Sci. 12, 153-182.

Bachelet, G., Dauvin, J.C., Sorbe, J.C., 2003. An updated checklist of marine and brackish water amphipoda (crustacea: peracarida) of the southern Bay of Biscay (NE Atlantic). Cah. Biol. Mar. 44, 121-151.

Basford, D., Eleftheriou, A., Raffaelli, D., 1990. The infauna and epifauna of the northern North Sea. Neth. J. Sea Res. 25, 165-173.

Bates, A.E., Pecl, G.T., Frusher, S., Hobday, A.J., Wernberg, T., Smale, D.A., Sunday, J.M., Hill, N.A., Dulvy, N.K., Colwell, R.K., Holbrook, N.J., Fulton, E.A., Slawinski, D., Feng, M., Edgar, G.J., Radford, B.T., Thompson, P.A., Watson, R.A., 2014. Defining and observing stages of climate-mediated range shifts in marine systems. Glob. Environ. Chang. 26, $27-38$.
Bellan-Santini, D., Diviacco, G., Krapp-Schickel, G., Myers, A.A., Ruffo, S., 1989. The amphipoda of the Mediterranean. Part 2. Gammaridea (Haustoriidae to Lysianassidae). Mem. Inst. Oceanogr. 13, 365-576 (Monaco).

Bellan-Santini, D., Karaman, G., Krapp-Schickel, G., Ledoyer, M., Myers, A.A., Ruffo, S. Schiecke, U., 1982. The amphipoda of the Mediterranean. Part 1. Gammaridae (Acanthonotozomatidae to Gammaridae). Mem. Inst. Oceanogr. 13, 1-364 (Monaco).

Bellan-Santini, D., Karaman, G., Krapp-Schickel, G., Ledoyer, M., Ruffo, S., 1993. The amphipoda of the Mediterranean. Part 3. Gammaridea (Melphidippidae to Talitridae), Ingolfiellidea, Caprellidea. Mem. Inst. Oceanogr. 13, 577-813 (Monaco).

Bergen, M., Weisberg, S.B., Smith, R., Cadien, D.B., Dalkey, A., Montagne, D.E., Stull, J.K., Velarde, R.G., Ranasinghe, J.A., 2001. Relationship between depth, sediment, latitude, and the structure of benthis infaunal assemblages on the mainland shelf of Southern California. Mar. Biol. 138, 637-647.

Bettencourt, A.M., Bricker, S.B., Ferreira, J.G., Franco, A., Marques, J.C., Melo, J.J., Nobre, A. Ramos, I., Reis, C.S., Salas, F., Silva, M.C., Simas, T., Wolff, W., 2004. Typology and reference conditions for Portuguese transitional and coastal waters. Development of Guidelines for the Application of the European Union Water Framework Directive. INAG/IMAR, Lisboa, Portugal (100 pp). (Available online at) http://www.ecowin. org/ticor.

Borges, P.A.V., Costa, A., Cunha, R., Gabriel, R., Gonçalves, V., Martins, A.F., Melo, I., Parente, M., Raposeiro, P., Rodrigues, P., Santos, R.S., Silva, L., Vieira, P., Vieira, V., 2010. A List of the Terrestrial and Marine Biota From the Azores. Princípia, Cascais (432 pp). (Available online at http://www.azoresbioportal.angra.uac.pt/files/publicacoes_Listagem_ ml.pdf).

Bouvier, E.L., 1940. Décapodes Marcheurs. Faune de France. 37. Féderation Française des Sociétés de Science Naturelle Office Central de Faunistique, Paris (404 pp).

Brandt, A., 1995. Peracarid fauna (crustacea, malacostraca) of the northeast water polynya off Greenland: documenting close benthic-pelagic coupling in the Westwind trough. Mar. Ecol. Prog. Ser. 121, 39-51.

Brooks, R.A., Purdy, C.N., Bell, S.S., Sulak, K.J., 2006. The benthic community of the eastern US continental shelf. A literature synopsis of benthic faunal resources. Cont. Shelf Res. $26,804-818$.

Cacabelos, E., Lourido, A., Troncoso, J.S., 2010. Composition and distribution of subtida and intertidal crustacean assemblages in soft-bottoms of the Ria de Vigo (NW Spain). Sci. Mar. 74 (3), 455-464.

Cartes, J.E., Mamouridis, V., Fanelli, E., 2011. Deep-sea suprabenthos assemblages (crustacea) off the Balearic Islands (western Mediterranean): mesoscale variability in diversity and production. J. Sea Res. 65, 340-354.

Carvalho, S., Cunha, M.R., Pereira, F., Pousão-Ferreira, P., Santos, M.N., Gaspar, M.B., 2012 The effect of depth and sediment type on the spatial distribution of shallow softbottom amphipods along the southern Portuguese coast. Helgol. Mar. Res. 66, 489-501.

Clarke, K.R., Gorley, R.N., 2006. PRIMER v.6: User Manual/Tutorial PRIMER-E. 6 (Plymouth, England). (190 pp).

Coll, M., Piroddi, C., Steenbeek, J., Kaschner, K., Lasram, F.B.R., Aguzzi, J., Ballesteros, E., Bianchi, C.N., Corbera, J., Dailianis, T., Danovaro, R., Estrada, M., Froglia, C., Galil, B.S., Gasol, J.M., Gertwagen, R., Gil, J., Guilhaumon, F., Kesner-Reyes, K., Kitsos, M.S., Koukouras, A., Lampadariou, N., Laxamana, E., López-Fé de la Cuadra, C.M., Lotze H.K., Martin, D., Mouillot, D., Oro, D., Raicevich, S., Rius-Barile, J., Saiz-Salinas, J.I., San Vicente, C., Somot, S., Templado, J., Turon, X., Vafidis, D., Villanueva, R., Voultsiadou, E., 2010. The biodiversity of the Mediterranean Sea estimates, patterns, and threats. PLOS ONE 5 (8), e11842.

Conradi, M., López-González, P.J., 1999. The benthic Gammaridea (crustacea, amphipoda) fauna of Algeciras Bay (strait of Gibraltar): distributional ecology and some biogeographical considerations. Helgol. Mar. Res. 53, 2-8.

Corbera, J., 1995. Check-list of Cumacea from Iberian waters. Misc. Zool. 18, 57-75.

Costa, A.C.C., 2012. Caracterização e cartografia da fauna intertidal das praias rochosas de Matosinhos. Dissertação de Mestrado. Universidade do Porto, Portugal (118 pp). (Available online at) http://hdl.handle.net/10216/65194.

Costello, M.J., Bouchet, P., Emblow, C.S., Legakis, A., 2006. European marine biodiversity inventory and taxonomic resources: state of the art and gaps in knowledge. Mar. Ecol. Prog. Ser. 316, 257-268.

Costello, M.J., Holmes, J.M.C., McGrath, D., Myers, A.A., 1989. A review and catalogue of the amphipoda (crustacea) in Ireland. Ir. Fish. Invest. B. 33, 1-70.

Cunha, M.M.P.R., 1999. Peracaridan crustacea in Ria de Aveiro (NW Portugal): taxonomic composition and spatio-temporal structure of the assemblages; life history and secondary production of Corophium multisetosum stock, 1952 (amphipoda, Corophiidae). Tese de Doutoramento. Universidade de Aveiro, Portugal (195 pp).

Cunha, M.R., Paterson, G.J.L., Amaro, T., Blackbird, S., de Stigter, H.C., Ferreira, C., Glover, A., Hilário, A., Kiriakoulakis, K., Neal, L., Ravara, A., Rodrigues, C.F., Tiago, Á., Billett, D.S.M. 2011. Biodiversity of macrofaunal assemblages from three Portuguese submarine canyons (NE Atlantic). Deep-Sea Res. Part II. 58, 2433-2447.

Cunha, M.R., Sorbe, J.C., Bernardes, C., 1997. On the structure of the neritic suprabenthic communities from the Portuguese continental margin. Mar. Ecol. Prog. Ser. 157, 119-137.

Cúrdia, J., Carvalho, S., Ravara, A., Gage, J.D., Rodrigues, A.M., Quintino, V., 2004. Deep macrobenthic communities from Nazaré submarine canyon (NW Portugal). Sci. Mar. 68, 171-180.

Dajoz, R., 1971. Précis d'Ecologie. Ed. Dunod, Paris (549 pp).

Dauvin, J.C., 1999. Mise à jour de la liste des espèces d'Amphipodes (crustacea: peracarida) présents en Manche. Cah. Biol. Mar. 40, 165-183.

Dauvin, J.C., 2015. History of benthic research in the English Channel: from general patterns of the communities to habitat mosaic description. J. Sea Res. 100, 32-45.

Dauvin, J.C., Bellan-Santini, D., 1985. Collection des Ampéliscidés d'Édouard Chevreux du Muséum national d'Histoire naturelle: description d' Ampelisca melitae et d'A monoculata n. spp. et redescription d'A. verga Reid. Bull. Mus. Natl. Hist. Nat. 7 (3), 659-675 (4A). 
Dauvin, J.C., Bellan-Santini, D., 2002. Les Crustacés amphipodes Gammaridea benthiques des côtes françaises metropolitaines: Bilan des connaissances. Crustac. Int. J. Crustac. Res. 75, 299-340.

Dauvin, J.C., Alizier, S., Vallet, C., Ruellet, T., 2010. Does the port 2000 harbour construction have an effect on the seine estuary suprabenthic community? Estuar. Coast. Shelf Sci. $86,42-50$.

Dauvin, J.C., Kendall, M., Paterson, G., Gentil, F., Jirkov, I., Sheader, M., De Lange, M., 1994. An initial assessment of polychaete diversity in the northeastern Atlantic Ocean. Biodivers. Lett. 2, 171-181.

Dauvin, J.C., Thiébaut, E., Gesteira, J.L.G., Ghertsos, K., Gentil, F., Ropert, M., Sylvand, B. 2004. Spatial structure of a subtidal macrobenthic community in the Bay of Veys (western Bay of Seine, English Channel). J. Exp. Mar. Biol. Ecol. 307, 217-235.

Dexter, D.M., 1988. The sandy beach fauna of Portugal. Arq. Mus. Bocage Nova Ser. 1 101-110.

Dolbeth, M., Ferreira, Ó., Teixeira, H., Marques, J.C., Dias, J.A., Pardal, M.A., 2007. Beach morphodynamic impact on a macrobenthic community along a subtidal depth gradient. Mar. Ecol. Prog. Ser. 352, 113-124.

Dos Santos, A., González-Gordillo, J.I., 2004. Illustrated keys for the identification of the Pleocyemata (crustacea: decapoda) zoeal stages, from the coastal region of southwestern Europe. J. Mar. Biol. Assoc. UK 84, 205-227.

Ellingsen, K.E., Gray, J.S., 2002. Spatial patterns of benthic diversity is there a latitudinal gradient along the Norwegian continental shelf? J. Anim. Ecol. 71, 373-389.

Ellingsen, K.E., Clarke, K.R., Somerfield, P.J., Warwick, R.M., 2005. Taxonomic distinctness as a measure of diversity applied over a large scale the benthos of the Norwegian continental shelf. J. Anim. Ecol. 74, 1069-1079.

Ferreira, M.C.S., 2009. Abundância e diversidade de Crustáceos dos canhões portugueses. Dissertação de Mestrado. Universidade de Aveiro, Portugal (65 pp). (Available online at) http://hdl.handle.net/10773/835.

Fiúza, A.F.G., 1983. Upwelling patterns off Portugal. In: Suess, E., Thiede, J. (Eds.), Coasta Upwelling: Its Sediment Record. Plenum Publishing Corporation, New York, pp. 85-98.

Freitas, R., Ricardo, F., Pereira, F., Sampaio, L., Carvalho, S., Rodrigues, A.M., Quintino, V. 2011. Benthic habitat mapping: concerns using a combined approach (acoustic, sediment and biological data). Estuar. Coast. Shelf Sci. 92, 598-606.

Freitas, R., Rodrigues, A.M., Quintino, V., 2003. Benthic biotopes remote sensing using acoustics. J. Exp. Mar. Biol. Ecol. 285-286, 339-353.

Freitas, R., Sampaio, L., Oliveira, J., Rodrigues, A.M., Quintino, V., 2006. Validation of soft bottom benthic habitats identified by single-beam acoustics. Mar. Pollut. Bull. 53, 72-79.

Gentil, F., Dauvin, J.C., 1988. Peut-on estimer le nombre total d'espèces d'un peuplement macrobenthique? Applications aux peuplements de substrat meuble de la Manche. Vie Milieu. 38, 207-212.

Glémarec, M., 1973. The benthic communities of the European North Atlantic continental shelf. Oceanogr. Mar. Biol. Annu. Rev. 11, 263-289.

Godet, L., Le Mao, P., Grant, C., Olivier, F., 2010. Marine invertebrate fauna of the Chausey archipelago: an annotated checklist of historical data from 1828 to 2008. Cah. Biol Mar. 51, 147-165.

Gomes, N.M.A., 2014. Construção de uma biblioteca de referência de DNA barcodes para Isópodes marinhos (crustacea isopoda) de Portugal e da Macaronésia. Dissertação de Mestrado. Universidade do Minho, Portugal (94 pp). (Available online at) http://hdl.handle.net/1822/34768.

Gooday, A.J., Bett, B.J., Escobar, E., Ingole, B., Levin, L.A., Neira, C., Raman, A.V., Sellanes, J., 2010. Habitat heterogeneity and its influence on benthic biodiversity in oxygen minimum zones. Mar. Ecol. 31 (1), 125-147.

Gray, J.S., 2000. The measurement of marine species diversity, with an application to the benthic fauna of the Norwegian continental shelf. J. Exp. Mar. Biol. Ecol. 250, 23-49.

Grémare, A., Amouroux, J.M., Vétion, G., 1998. Long-term comparison of macrobenthos within the soft bottoms of the bay of Banyuls-Sur-mer (northwestern Mediterranean Sea). J. Sea Res. 40, 281-302.

Grimes, M.S., 2010. Peuplements benthiques des substrats meubles de la côte Algerienne: Taxonomie, structure et statut écologique. Thèse de doctorat. Université d'Oran Faculté des Sciences, République Algérienne Démocratique et Populaire (360 pp). (Available online at) https://www.pnst.cerist.dz (cote: TH3599).

Guerra-García, J.M., Navarro-Barranco, C., Corzo, J., Cobos-Muñoz, V., García-Adiego, E.M. Giménez, F.S., García-Gómez, J.C., 2013. An illustrated key to the soft-bottom caprellids (amphipoda) of the Iberian peninsula. Helgol. Mar. Res. 67, 321-336.

Gurriarán, E.G., Méndez, M., 1985. Crustáceos decápodos das costas de Galicia. I. Brachyura. Cuadernos da Área de Ciencias Biolóxicas vol. 2. Seminário de Estudos Galegos (Ed. do Castro, O Castro-Sada, Coruña). (242 pp).

Hily, C., Le Lo'ch, F., Grall, J., Glémarec, M., 2008. Soft bottom macrobenthic communities of North Biscay revisited: long-term evolution under fisheries-climate forcing. Estuar Coast. Shelf Sci. 78, 413-425.

Holdich, D.M., Jones, J.A., 1983. Tanaids. Synopses of the British Fauna (New Series) No. 27 Cambridge University Press, Cambridge - London - New york (98 pp).

Howson, C.M., Picton, B.E., 1997. The species directory of the marine fauna and flora of the British Isles and surrounding seas. Ulster Museum Publication 276. The Ulster Museum, Belfast, UK (508 pp)

Ingle, R.W., 1983. Shallow water crabs. Synopses of the British Fauna (New Series). Cambridge University Press, Cambridge - London - New york No. 25. (206 pp).

Ingle, R.W., 1993. Hermit Crabs of the Northeastern Atlantic Ocean and Mediterranean Sea: An Illustrated Key. Natural History Museum and Champman \& Hall, London (495 pp)

Ingle, R.W., Christiansen, M.E., 2004. Lobsters, mud shrimps and anomuran crabs. Synopses of the British Fauna (New Series). Field Studies Council, Shrewsbury No. 55. (271 pp).

Jacquotte, R., 1962. Etude des fonds de Maerl de Mediterranee. Rec. Trav. St. Mar. Endoume. 26 (41), 141-216.
Jones, N.S., 1976. British Cumaceans. Synopses of the British Fauna (New Series). Academic Press, London No. 17. (66 pp).

Junoy, J., Castelló, J., 2003. Catálogo de las especies ibéricas y baleares de isópodos marinos (crustacea: isopoda). Bol. Inst. Esp. Oceanogr. 19 (1-4), 293-325.

Karakassis, I., Eleftheriou, A., 1997. The continental shelf of Crete: structure of macrobenthic communities. Mar. Ecol. Prog. Ser. 160, 185-196.

Lagardère, J.P., 1973. Distribuition des Décapodes dans le Sud du Golfe de Gascogne. Rev. Trav. Inst. Pech. Marit. 37 (1), 77-95.

Lambshead, P., Tietjen, J., Timothy, F., Jensen, P., 2000. Latitudinal diversity gradients in the deep sea with special reference to North Atlantic nematodes. Mar. Ecol. Prog. Ser. 194, 159-167.

Levin, L.A., Gage, J.D., 1998. Relationships between oxygen, organic matter and the diversity of bathyal macrofauna. Deep-Sea Res. Part II. 45, 129-163.

Lincoln, R.J., 1979. British Marine Amphipoda: Gammaridea. British Museum (Natural History), London (658 pp).

López-Jamar, E., Cal, R.M., González, G., Hanson, R.B., Rey, J., Santiago, G., Tenore, K.R., 1992. Upwelling and outwelling effects on the benthic regime of the continental shelf off Galicia, NW Spain. J. Mar. Res. 50, 465-488.

Lourido, A., Moreira, J., Troncoso, J.S., 2008. Assemblages of peracarid crustaceans in subtidal sediments from the Ría de Aldán (Galicia, NW Spain). Helgol. Mar. Res. 62, 289-301.

Lyubina, O.S., Bryazgin, V.F., Raznovskaya, S.V., 2014. The composition and distribution of benthic amphipods (crustacea: amphipoda) in the Southern Barents Sea. Russ. J. Mar. Biol. 40, 241-254.

Mamede, R., Rodrigues, A.M., Freitas, R., Quintino, V., 2015. Single-beam acoustic variability associated with seabed habitats. J. Sea Res. 100, 152-159.

Marco-Herrero, E., Abelló, P., Drake, P., García-Raso, J.E., González-Gordillo, J.I., Guerao, G., Palero, F., Cuesta, J.A., 2015. Annotated checklist of brachyuran crabs (crustacea: decapoda) of the Iberian peninsula (SW Europe). Sci. Mar. 79 (2), 243-256.

Marques, J.C. 1989. Amphipoda (crustacea) bentónicos da Costa Portuguesa: Estudo taxonómico, ecológico e biogeográfico. Universidade de Coimbra, Portugal, Tese de doutoramento (384 pp)

Marques, J.C., Bellan-Santini, D., 1991. Gammaridea and Caprellidea (crustacea amphipoda) of the Portuguese south-western continental shelf: taxonomy and distributional ecology. Bijdr. Dierk. 61, 65-87.

Marques, J.C., Bellan-Santini, D., 1993. Biodiversity in the ecosystem of the Portuguese continental shelf: distributional ecology and role of benthic amphipods. Mar. Biol. $115,555-564$.

Martínez, J., Adarraga, I., Ruiz, J.M., 2007. Tipificación de poblaciones bentónicas de los fondos blandos de la plataforma continental de Guipúzcoa (sureste del golfo de Vizcaya). Bol. Inst. Esp. Oceanogr. 23, 85-110.

Martins, R., Azevedo, M.R., Mamede, R., Sousa, B., Freitas, R., Rocha, F., Quintino, V., Rodrigues, A.M., 2012. Sedimentary and geochemical characterization and provenance of the Portuguese continental shelf soft-bottom sediments. J. Mar. Syst. 91, 41-52.

Martins, R., Quintino, V., Rodrigues, A.M., 2013a. Diversity and spatial distribution patterns of the soft-bottom macrofauna communities on the Portuguese continental shelf. J. Sea Res. 83, 173-186.

Martins, R., Sampaio, L., Quintino, V., Rodrigues, A.M., 2014. Diversity, distribution and ecology of benthic molluscan communities on the Portuguese continental shelf. J. Sea Res. 93, 75-89.

Martins, R., Sampaio, L., Rodrigues, A.M., Quintino, V., 2013b. Soft-bottom Portuguese continental shelf polychaetes: diversity and distribution. J. Mar. Syst. 123-124, 41-54.

Mauchline, J., 1984. Euphausiid, Stomatopod and Leptostracan Crustaceans. Synopses of the British Fauna (New Series) No. 30 E.J Brill, London (91 pp)

Menioui, M., 1998. Biodiversité de la Faune Marine. Étude Nationale sur la Biodiversité. Observatoire National de l'Environnement du Maroc (113 pp). (Available online at http://ma.chm-cbd.net/implementation/enb_ma/Faune_Marine_du_Maroc.pdf).

Montaudouin, X., Sauriau, P.G., 2000. Contribution to a synopsis of marine species richness in the Pertuis Charentais Sea with new insights in soft-bottom macrofauna of the Marennes-Oléron Bay. Cah. Biol. Mar. 41, 181-222.

Moreira, J., Díaz-Agras, G., Candás, M., Señaris, M.P., Urgorri, V., 2009. Leptostracans (crustacea: phyllocarida) from the Ría de Ferrol (Galicia, NW Iberian Peninsula), with description of a new species of Nebalia Leach, 1814. Sci. Mar. 73, 269-285.

Moreira, J., Gestoso, L., Troncoso, J.S., 2003. Two new species of Sarsinebalia (crustacea, leptostraca) from the Northeast Atlantic, with comments on the genus. Sarsia 88, 189-209.

Moreira, M.H., Queiroga, H., Machado, M.M., Cunha, M.R., 1993. Environmental gradientes in a southern Europe estuarine system: Ria de Aveiro, Portugal. Implications for soft bottom macrofaunal colonization. Neth. J. Aquat. Ecol. 27, 465-482.

Moulaert, I., Hostens, K., Hillewaert, H., Wittoeck, J., 2007. Spatial variation of the macrobenthos species and communities of the Belgian Continental Shelf. 09. ICES, Copenhagen Denmark (2007/A).

Munari, C., Mistri, M., 2008. Biodiversity of soft-sediment benthic communities from Italian transitional waters. J. Biogeogr. 35, 1622-1637.

Munilla, T., San Vicente, C., 2005. Suprabenthic biodiversity of Catalan beaches (NW Mediterranean). Acta Oecol. 27, 81-91.

Muñoz, J.E.G., Manjón-Cabeza, M.E., Raso, J.E.G., 2008. Decapod crustacean assemblages from littoral bottoms of the Alborán Sea (Spain, west Mediterranean Sea): spatial and temporal variability. Sci. Mar. 72, 437-449.

Nascimento, S., Franco, P., Sousa, F., Dias, J., Neves, F., 2012. Automated computational delimitation of SST upwelling areas using fuzzy clustering. Comput. Geosci. 43, 207-216.

Naylor, E.E., 1972. British marine isopods. Synopses of the British Fauna (New Series). Academic Press, London - New York No. 3. (86 pp).

Neves, A.M.S.F., 1967. Crustáceos Decápodos da região de Cascais (Portugal) existentes no Museu Bocage. Arq. Mus. Bocage Ser. 2 (1), 257-281.

Neves, A.M.S.F., 1990. On a small collection of crustacea decapoda from Sagres (Algarve). Arq. Mus. Bocage Nova Ser. 1 (45), 661-695. 
Nilsson-Cantell, C.-A., 1978. Cirripedia Thoracica and Acrothoracica. Marine Invertebrates of Scandinavia No. 5 Universitetsforlaget, Oslo, Norway (133 pp).

Oliveira, A., Santos, A.I., Rodrigues, A., Vitorino, J., 2007. Sedimentary particle distribution and dynamics on the Nazaré canyon system and adjacent shelf (Portugal). Mar. Geol. 246, 105-122.

Ospina-Alvarez, N., Prego, R., Álvarez, I., deCastro, M., Álvarez-Ossorio, M.T., Pazos, Y., Campos, M.J., Bernárdez, P., Garcia-Soto, C., Gómez-Gesteira, M., Varela, M., 2010. Oceanographical patterns during a summer upwelling-downwelling event in the northern Galician rias: comparison with the whole Ria system (NW of Iberian peninsula). Cont. Shelf Res. 30, 1362-1372.

Pereira, S.G., Lima, F.L., Queiroz, N.C., Ribeiro, P.A., Santos, A.M., 2006. Biogeographic patterns of intertidal macroinvertebrates and their association with macroalgae distribution along the Portuguese coast. Hydrobiologia 555, 185.

Pérès, J.M., Picard, J., 1964. Nouveau Manuel de bionomie benthique. Rec. Trav. St. Mar. Endoume. 31 (47), 5-137.

Petryashov, V.M., 2009. The biogeographical division of the Arctic and North Atlantic by the mysid (crustacea: mysidacea) fauna. Russ. J. Mar. Biol. 35, 97-116.

Poore, G.C.B., 2001. Families and genera of Isopoda Anthuridea. In: Kensley, B., Brusca, R.C. (Eds.), Isopod Systematics and EvolutionCrustacean Issues 13. Balkema, Rotterdam, The Netherlands, pp. 63-173.

Poore, G., Schotte, M., 2015. Cortezura Schultz, 1977. In: Boyko, C.B., Bruce, N.L., Merrin, K.L., Ota, Y. Poore, G.C.B., Taiti, S., Schotte, M., Wilson, G.D.F. (Eds.), World Marine, Freshwater and Terrestrial Isopod Crustaceans database (Accessed through: World Register of Marine Species at http://www.marinespecies.org/aphia.php?p$=$ taxdetails\&id $=248640$ on 2016-03-08).

Quintino, V., Gentil, F., Rodrigues, A.M., Peneda, M.C., 1987. Macrozoobenthic community structure in the lagoon of Albufeira, western coast of Portugal. J. Exp. Mar. Biol. Ecol. 106, 229-241.

Quintino, V., Rodrigues, A.M., Gentil, F., 1989. Assessment of macrozoobenthic communities in the lagoon of Óbidos, western coast of Portugal. Sci. Mar. 53, 645-654.

Quintino, V., Rodrigues, A.M., Ré, A., Pestana, M.P., Silva, S., Castro, H., 2001. Sediment alterations in response to marine outfall operation off Lisbon, Portugal: a sediment quality triad study. J. Coast. Res. Spec. Issue 34, 535-549.

Rees, H.L., Pendle, M.A., Waldock, R., Limpenny, D.S., Boyd, S.E., 1999. A comparison of benthic biodiversity in the North Sea, English Channel, and Celtic seas. ICES J. Mar Sci. 56, 228-246.

Reid, D.M., 1951. Report on the Amphipoda (Gammaridea and Caprellidea) of the coast of Tropical West Africa. Atlantide Rep 2, 189-291.

Reis, C.S., Marques, V.M., Calvário, J., Marques, J.C.M., Melo, R., Santos, R., 1982. Contribuição para o estudo dos povoamentos bentónicos (substrato móvel) da costa ocidental portuguesa. Oecol. Aquat. 6, 91-105.

Reise, K., 1991. Macrofauna in mud and sand of tropical and temperate tidal flats. In: Elliott, M., Ducrotory, J.P. (Eds.), Estuaries and Coasts: Spatial and Temporal Intercomparisons. Olsen and Olsen, Fredenborg, pp. 211-216.

Retière, C., 1979. Contribution à la connaissance des peuplements benthiques du Golfe Normano-Breton. Thèse de doctorat d'Etat. Université Rennes 1, France (431 pp).

Rodrigues, A.M., Quintino, V., 1987. Avaliação dos efeitos dos efluentes das indústrias de pasta de papel SOPORCEL e CELBI sobre a macrofauna bentónica do meio receptor. 1롤 Conferência Nacional Sobre a Qualidade do Ambiente. 1, pp. 250-262.

Rodrigues, A.M., Quintino, V., 1993. Horizontal biosedimentary gradientes across the Sado estuary, western coast of Portugal. Neth. J. Aquat. Ecol. 27, 449-464.

Rodrigues, A.M., Meireles, S., Pereira, T., Gama, A., Quintino, V., 2006. Spatial patterns of benthic macroinvertebrates in intertidal areas of a southern European estuary: the Tagus, Portugal. Hydrobiologia 555, 99-113.

Rodrigues, A.M., Quintino, V., Pereira, F., Freitas, R., 2012. Alterations in macroinvertebrate spatial patterns in coastal lagoons: Óbidos (NW coast of Portugal) 1984 versus 2002. Estuar. Coast. Shelf Sci. 110, 176-189.
Rodrigues, A.M., Quintino, V., Sampaio, L., Freitas, R., Neves, R., 2011. Benthic biodiversity patterns in Ria de Aveiro, Western Portugal: environmental-biological relationships. Estuar. Coast. Shelf Sci. 95, 338-348.

Roy, K., Jablonski, D., Valentine, J.W., 2004. Beyond species richness: biogeographic patterns and biodiversity dynamics using other metrics of diversity. In: Lomolino, M.V., Heaney, I.R. (Eds.), Frontiers of Biogeography: New Directions in the Geography of Nature. Sinauer, Sunderland, USA, pp. 151-170.

Roy, K., Jablonski, D., Valentine, J.W., Rosenberg, G., 1998. Marine latitudinal diversity gradients: tests of causal hypotheses. Proc. Natl. Acad. Sci. U. S. A. 95, 3699-3702.

Ruppert, E.E., Barnes, R.D., 1994. Invertebrate Zoology. sixth ed. Saunders College Publishing, Orlando, Forida (1056 pp).

Saldanha, L., 1997. Fauna submarina atlântica. Publicações Europa-América, Mem Martins (364 pp).

Serrano, A., Sánchez, F., García-Castrillo, G., 2006. Epibenthic communities of trawlable grounds of the Cantabrian Sea. Sci. Mar. 70 (S1), 149-159.

Silva, S., Ré, A., Pestana, P., Rodrigues, A.M., Quintino, V., 2004. Sediment disturbance off the Tagus estuary, western Portugal: chronic contamination, sewage outfall, and runoff events. Mar. Pollut. Bull. 49, 154-162.

Smaldon, G., 1979. British Coastal Shrimps and Prawns. Synopses of the British Fauna (New Series) No. 15 Academic Press, London (126 pp).

Spalding, M., Fox, H., Allen, G.R., Davidson, N., Ferdana, Z.A., Finlayson, M., Halpern, B.S. Jorge, M.A., Lombana, J.A., Lourie, S.A., Martin, K.D., Mcmanus, E., Molnar, J., Recchia, C.A., Robertson, J., 2007. Marine ecoregions of the world: a bioregionalisation of coastal and shelf areas. Bioscience 57, 573-583.

Stransky, B., Brandt, A., 2010. Occurrence, diversity and community structures of peracarid crustaceans (crustacea, malacostraca) along the southern shelf of Greenland. Polar Biol. 33, 851-867.

Tattersall, W.M., Tattersall, O.S., 1951. The British Mysidacea. Ray Society, London (460 $\mathrm{pp})$.

Thorson, G., 1957. Bottom communities (sublittoral or shallow shelf). In: Hedgpeth, J.W (Ed.), Treatise on Marine Ecology and Paleoecology. Geological Society of America USA, pp. 461-534.

Udekem d'Acoz, C. d.', 1999. Inventaire et distribution des crustacés décapodes de l'Atlantique nord-oriental, de la Méditerranée et des eaux continentales adjacentes au nord de $25^{\circ} \mathrm{N}$. Patrimoines naturels (Muséum National d' Histoire Naturelle/Service du Patrimoine Naturel). 40 (383 pp).

Vale, M., Cabral, H., Andrade, F., 2010. Distribution and structure of the upper sublittoral macrobenthic communities of Tróia sand beaches (Setúbal, Portugal) and their relationship with environmental factors. J. Environ. Monit. 2, 964-972.

Vanquickelberghe, V., 2004. Spatial distribution and biodiversity patterns of the hyperbenthos along NE Atlantic continental margins. PhD Thesis. University of Gent, Belgium (239 pp). (Available online at) http://hdl.handle.net/1854/LU-470516.

Weston, D.P., 1988. Macrobenthos-sediment relationships on the continental sheff off Cape Hatteras, North Carolina. Cont. Shelf Res. 8 (3), 267-286.

Whittaker, R.H., 1960. Vegetation of the Siskiyou Mountains, Oregon and California. Ecol. Monogr. 30, 279-338.

Witman, J.D., Etter, R.J., Smith, F., 2004. The relationship between regional and local species diversity in marine benthic communities: a global perspective. Proc. Natl. Acad. Sci. U. S. A. 101 (44), 15664-15669.

Zariquiey Alvarez, R., 1968. Crustáceos decápodos ibéricos. Consejo Superior de Investigaciones Científicas. Patronato Juan de la Cierva. Série: Investigación pesquera. 32 (Barcelona). (510 pp).

Zavodnik, D., Pallaoro, A., Jaklin, A., Kovacic, M., Arko-Pijevac, M., 2005. A benthos survey of the Senj Archipelago (North Adriatic Sea, Croatia). Acta Adriat. 46 (Suppl. 2), 3-68.

Zenetos, A., Christianidis, S., Pancucci, M.A., Simboura, N., Tziavos, C., 1997. Oceanologic study of an open coastal area in the Ionian Sea with emphasis on its benthic fauna and some zoogeographical remarks. Oceanol. Acta 20, 437-451. 